\title{
MAKROZVYŠKY PESTOVANÝCH RASTLÍN V HROBOCH Z DOBY POPOLNICOVÝCH POLÍ V CINOBANI ${ }^{1}$
}

\author{
Jana Mihályiová - Vladimír Mitáš
}

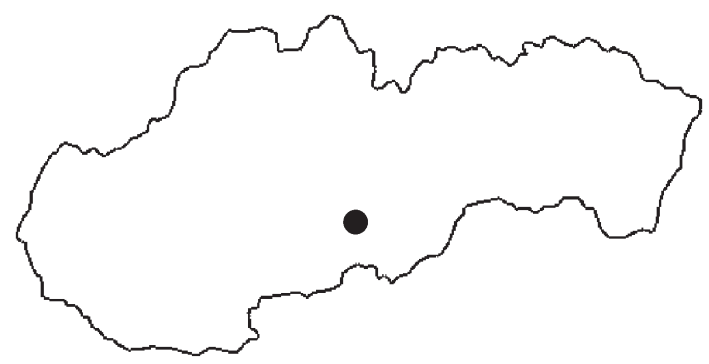

DOI: https://doi.org/10.31577/szausav.2019.65.2

Key words: Cinobaňa, burial ground, Urnfield period, macroremains of cultivated plants

\section{Macroremains of Cultivated Plants in Burials from the Urnfield Period in Cinobaňa}

The authors pay closer attention to macroremains of cultivated plants at the cremation burial ground from the Late Bronze Age (around 1200-750 BC) in Cinobaňa, Poltár district. 314 burials were systematically investigated and 730 archaeobotanical samples were collected between 2008 and 2014. Among the samples, charcoals from deciduous species used at cremation prevail. Macroremains of cultivated plants were identified only in seven burials and were taken from pottery vessels of various types and functions. In five cases they come from pea (Pisum sativum), one comes from naked barley (Hordeum vulgare var. coeleste) and one from proso millet (Panicum miliaceum). The selected burials belong mainly to the Kyjatice culture, one to Piliny culture. The assortment of plants from Cinobaña which has been preserved thanks to the burial rite is an indirect testimony of their cultivation in the Urnfield period in the southwest of the Slovenské rudohorie mountains.

\section{ÚVOD}

V príspevku sa bližšie venujeme menšiemu súboru zuholnatených makrozvyškov pestovaných rastlín - obilnín a strukovín, ktoré obsahovali výplne niektorých keramických nádob z doby popolnicových polí. Tie boli súčastou hrobovej výbavy na žiarovom pohrebisku z mladej a neskorej doby bronzovej (okolo 1200-750 pred n. 1.) v Cinobani, okres Poltár. Ide o jedno z najlepšie preskúmaných nálezísk kultúrneho komplexu juhovýchodných popolnicových polí (kultúr pilinskej a kyjatickej) na juhu stredného Slovenska a v priestore rozšírenia uvedených kultúr vôbec (Furmánek 2015, 190, 191, obr. 149).

Geomorfologická pozícia Cinobane je totožná s juhozápadným okrajom Slovenského rudohoria, západom Revúckej vrchoviny a Cinobanským predhorím. Pohrebisko sa nachádza severozápadne od obce na úpätí dominantnej hory Strieborná (718 m n. m.), na vrchole ktorej sú zvyšky hradiska kyjatickej kultúry. Odkrytá plocha pohrebiska leží v nadmorskej výške okolo $400 \mathrm{~m}$, na východnom okraji polohy Jarčanisko (obr. 1). K obom zmieneným miestam s nálezmi z doby popolnicových polí prislúcha súdobé sídlisko. Je v polohe Krivé zeme južne od pohrebiska v nadmorskej výške asi $350 \mathrm{~m}$ a delí ho od neho hlboký jarok.

Od začiatku systematického terénneho výskumu lokality (obr. 2), t. j. od roku 2008 (Furmánek/Mitáš 2010a; 2011; 2013; Mitáš/Furmánek 2015b; 2016; 2017; 2018), sa kládol dôraz na interdisciplinárnu spoluprácu (Mitáš/Furmánek 2015a, 160, 161). Bolo tomu tak až do roku 2014 (Furmánek/Mitáš, v tlači), kedy sa terénne práce pozastavili. Archeológovia, vedúci výskumu V. Furmánek so spoluvedúcim i spoluautorom príspevku, priamo v teréne úzko kooperovali s odborníkmi viacerých vedných disciplín, najmä však s antropológom a archeobotanikom. S ohladom na tému príspevku už v úvode zdôrazňujeme, že obsahy

1 Práca vznikla v rámci grantového projektu 01/0243/17 agentúry VEGA a bola podporovaná Agentúrou na podporu výskumu a vývoja na základe Zmluvy č. APVV-16-0441. Príspevok je rozšírenou verziou vývesky Makrozvyšky pestovaných rastlín zo žiarových hrobov pilinskej a kyjatickej kultúry v Cinobani (okr. Poltár), ktorú autori prezentovali na medzinárodnom podujatí 13. konferencia environmentálnej archeológie/„Človek a krajina...”, 6.-7. februára 2017 v Nitre. 


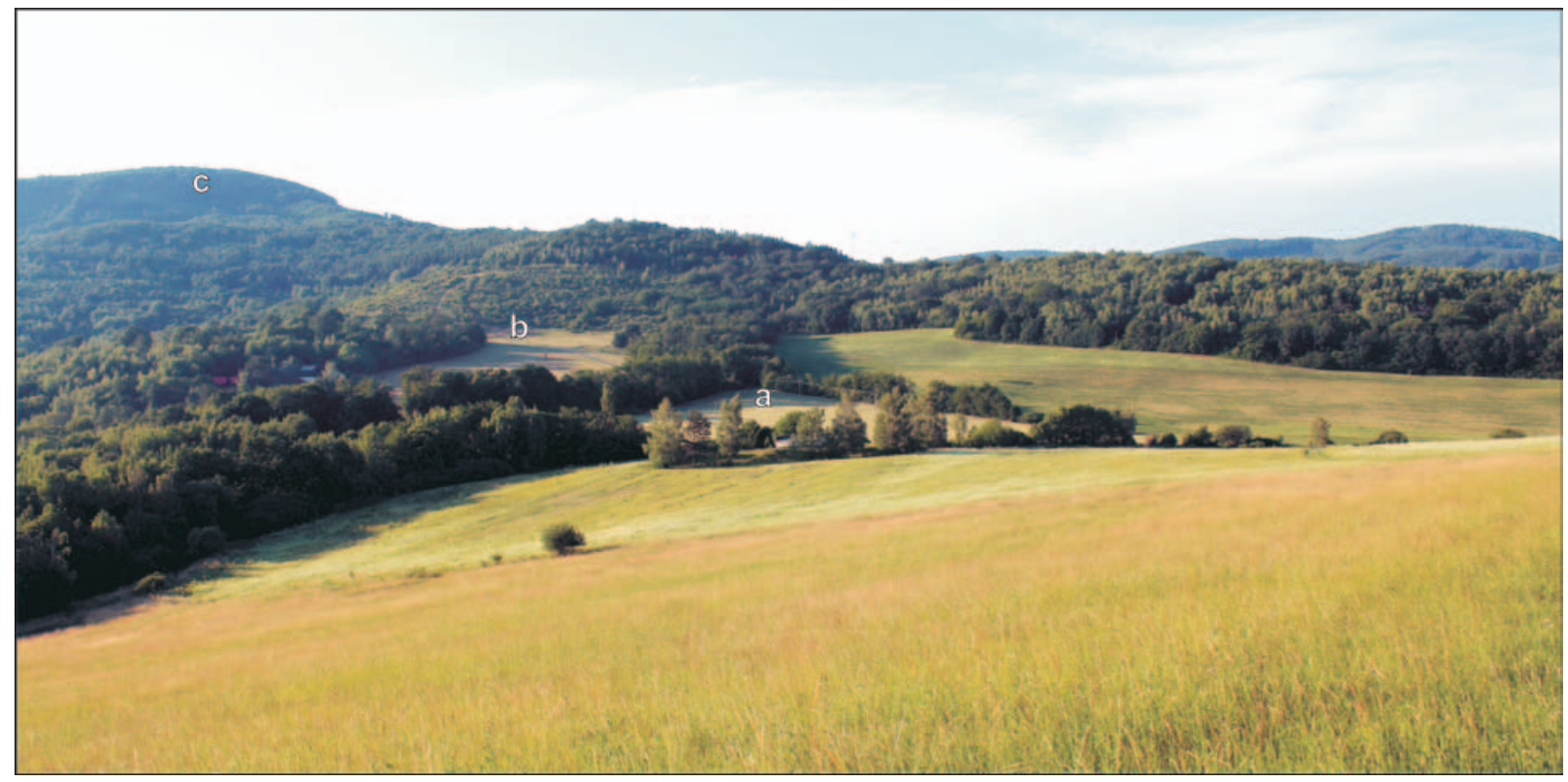

Obr. 1. Cinobaňa. Miesta nálezísk z doby popolnicových polí v krajine. Legenda: a - sídlisko; b - pohrebisko; c - hradisko. Foto V. Mitáš.

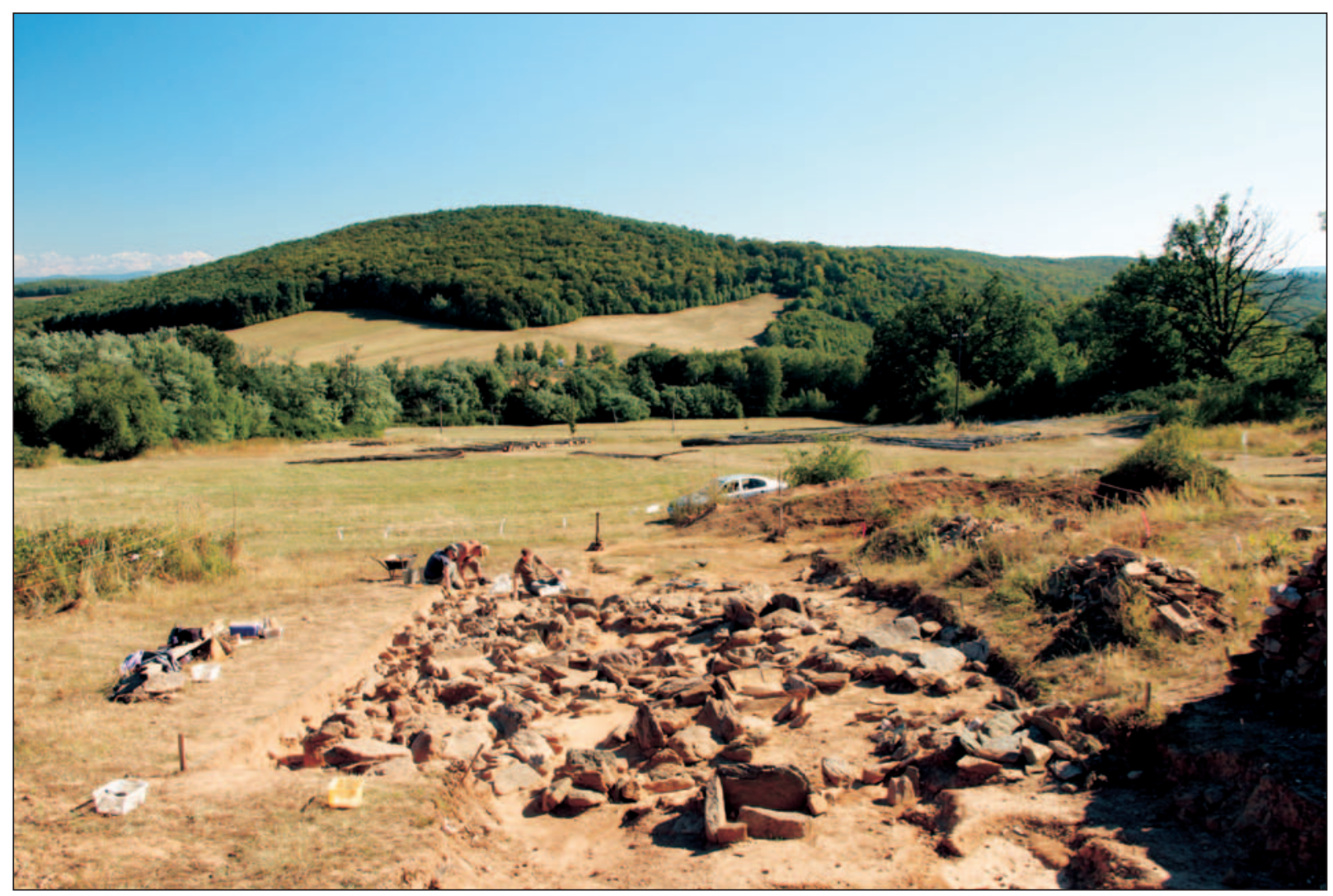

Obr. 2. Cinobaňa. Výskum pohrebiska v roku 2013. Foto V. Mitáš. 


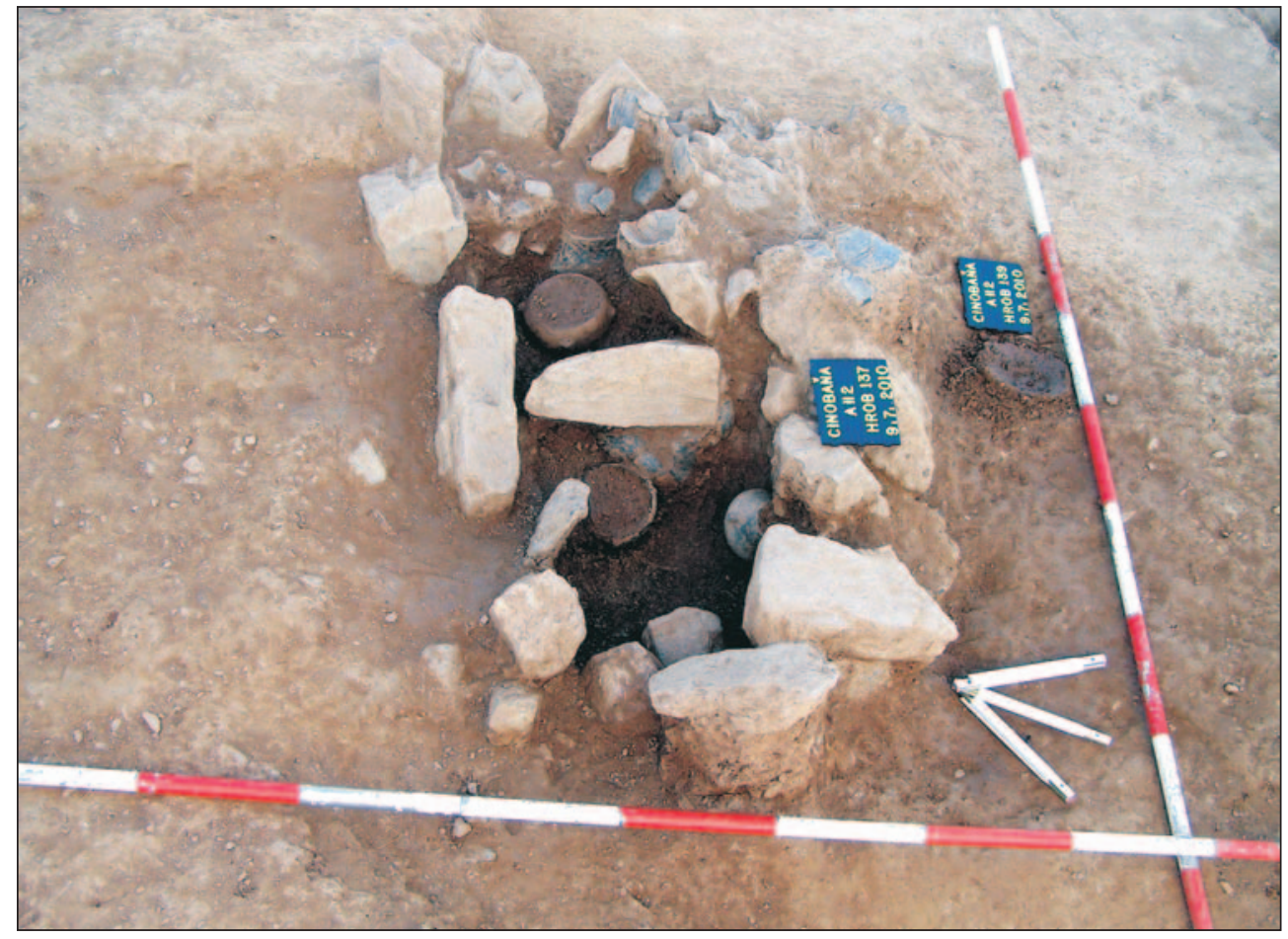

Obr. 3. Cinobaňa. Hrob 137/10. Foto V. Mitáš.

nádob (urien aj príloh) sa odoberali premyslene a systematicky. Prihliadalo sa na získanie maximálneho počtu vzoriek z čo najlepšie zachovaných (kompaktných) nádob a vo vybraných prípadoch z obsahov celého vnútra skrinkových hrobov. Po ich základnom spracovaní na výskumnej základni v Cinobani boli zuhol'natené rastlinné makrozvyšky podrobené detailnej analýze v Archeologickom ústave SAV v Nitre. Laboratórny rozbor všetkých výskumných sezón pohrebiska je v súčasnosti ukončený. Parciálne výsledky archeobotanického bádania boli publikované v zborníku referátov z XII. medzinárodnej konferencie Doba popolnicových polí a doba halštatská (Mihályiová 2015b).

\section{MATERIÁL}

Zvyšky plodín sa v Cinobani našli vo výplni siedmich žiarových hrobov. Tieto hroby, s výnimkou jedného hrobu pilinskej kultúry, prislúchajú kyjatickej kultúre. Vyplýva to z dominantného zastúpenia, a teda i vyššieho počtu ovzorkovaných hrobov kyjatickej kultúry na preskúmanej ploche pohrebiska z mladej a neskorej doby bronzovej. V žiadnom z hodnotených hrobov nebol spozorovaný sekundárny „zásah“ z doby laténskej (Mitáš/Furmánek 2015a, 171, 174) alebo z novoveku (Mitáš 2016, $173,177)$.

\section{KATALÓG HROBOV S ARCHEOLOGIZOVANÝMI NÁLEZMI PESTOVANÝCH RASTLÍN}

Usporiadaný je podla čísel hrobov s indexom podla jednotlivých sezón. Text obsahuje ich datovanie a opis nálezovej situácie.

- Hrob 137/10 (obr. 3) - neskorá doba bronzová, kyjatická kultúra. Kameňmi naznačenú skrinku hrobu prekrývali rôzne vel'ké kamene. V relatívne priestrannej skrinke obdížnikového pôdorysu, medzi kameňmi, ako aj na kameňoch skrinky bol uložený početný keramický inventár. Pozostával najmenej zo 14 nádob. Spálené kosti boli identifikované vo viacerých nádobách (1, 3, 4, 5 atd.), poprípade rozsypané okolo nich. V nádobe 2, miske s objemom 0,3 l, sa našlo semeno hrachu siateho (Pisum sativum). 


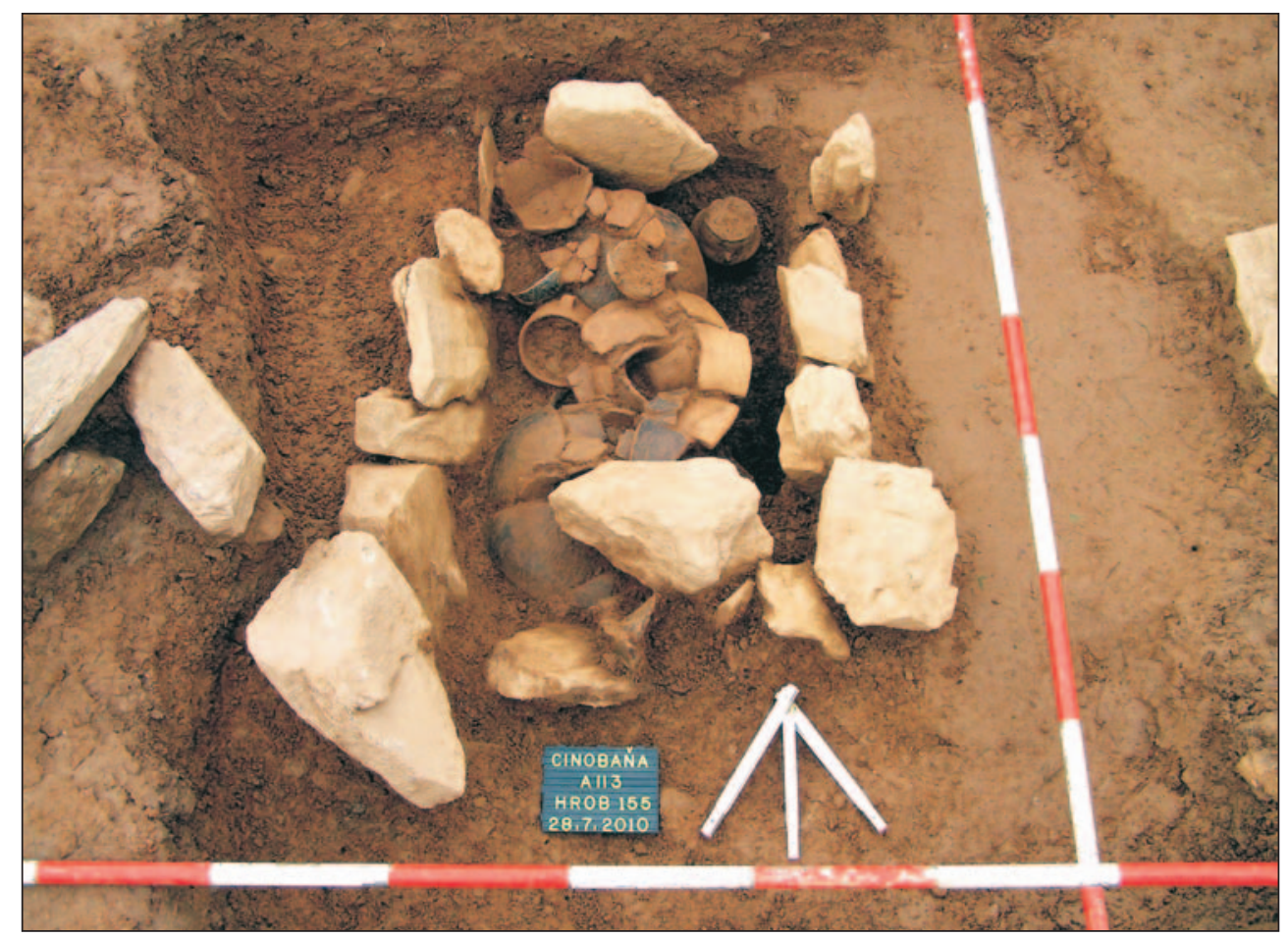

Obr. 4. Cinobaňa. Hrob 155/10. Foto V. Mitáš.

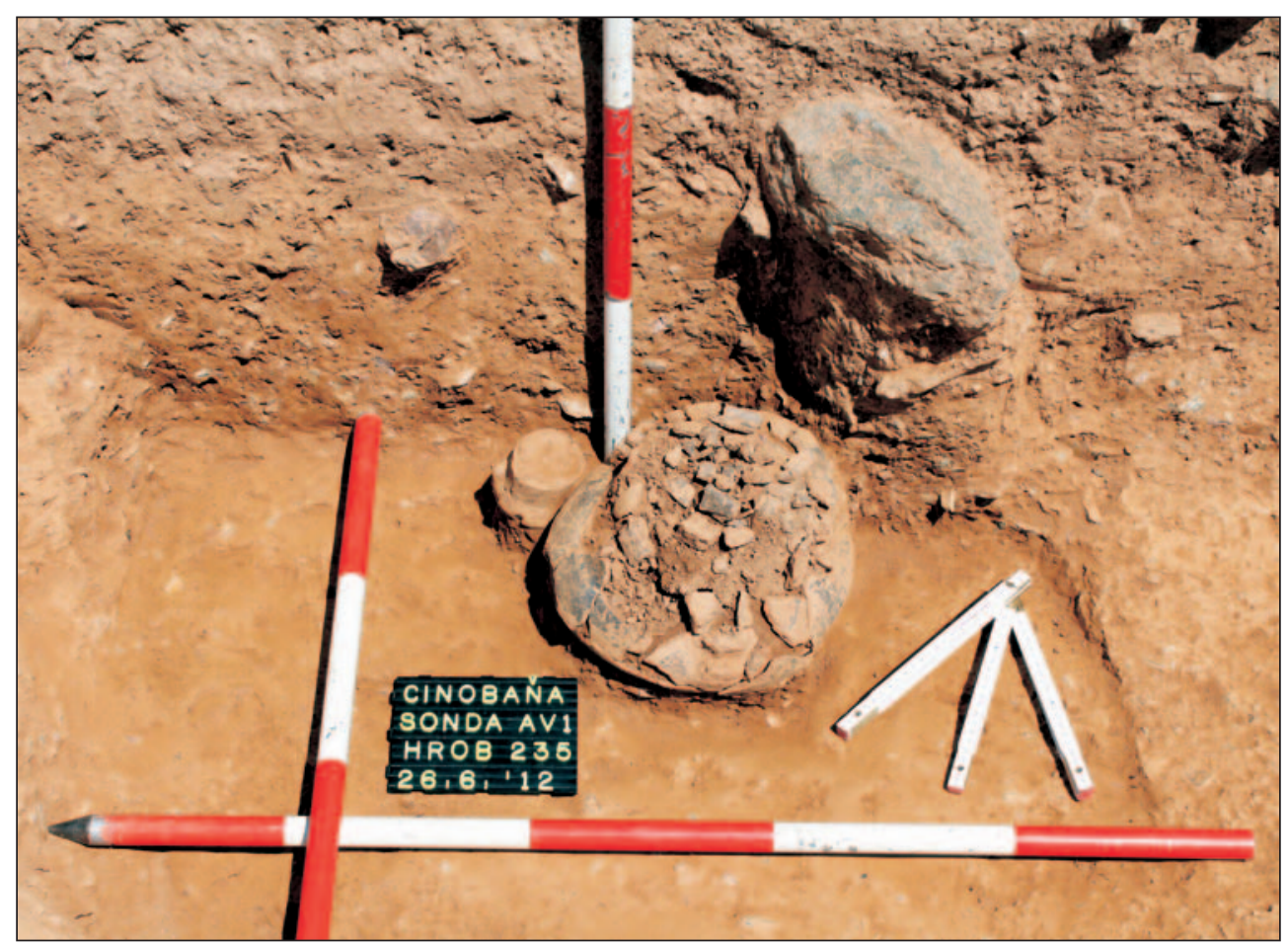

Obr. 5. Cinobaňa. Hrob 235/12. Foto V. Mitáš. 

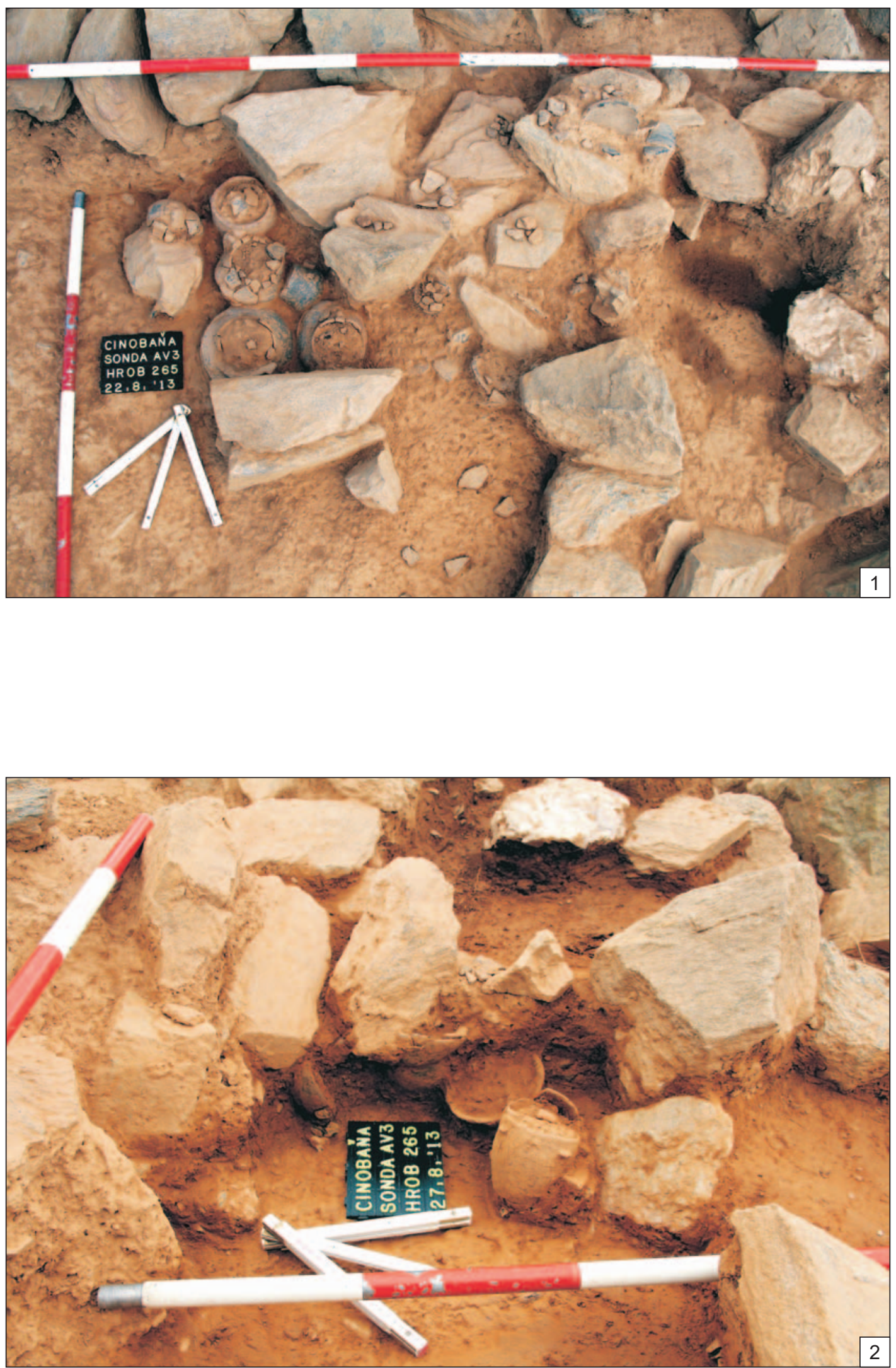

Obr. 6. Cinobaňa. Hrob 265/13. 1 - celok; 2 - detail miesta archeobotanického nálezu. Foto V. Mitáš. 


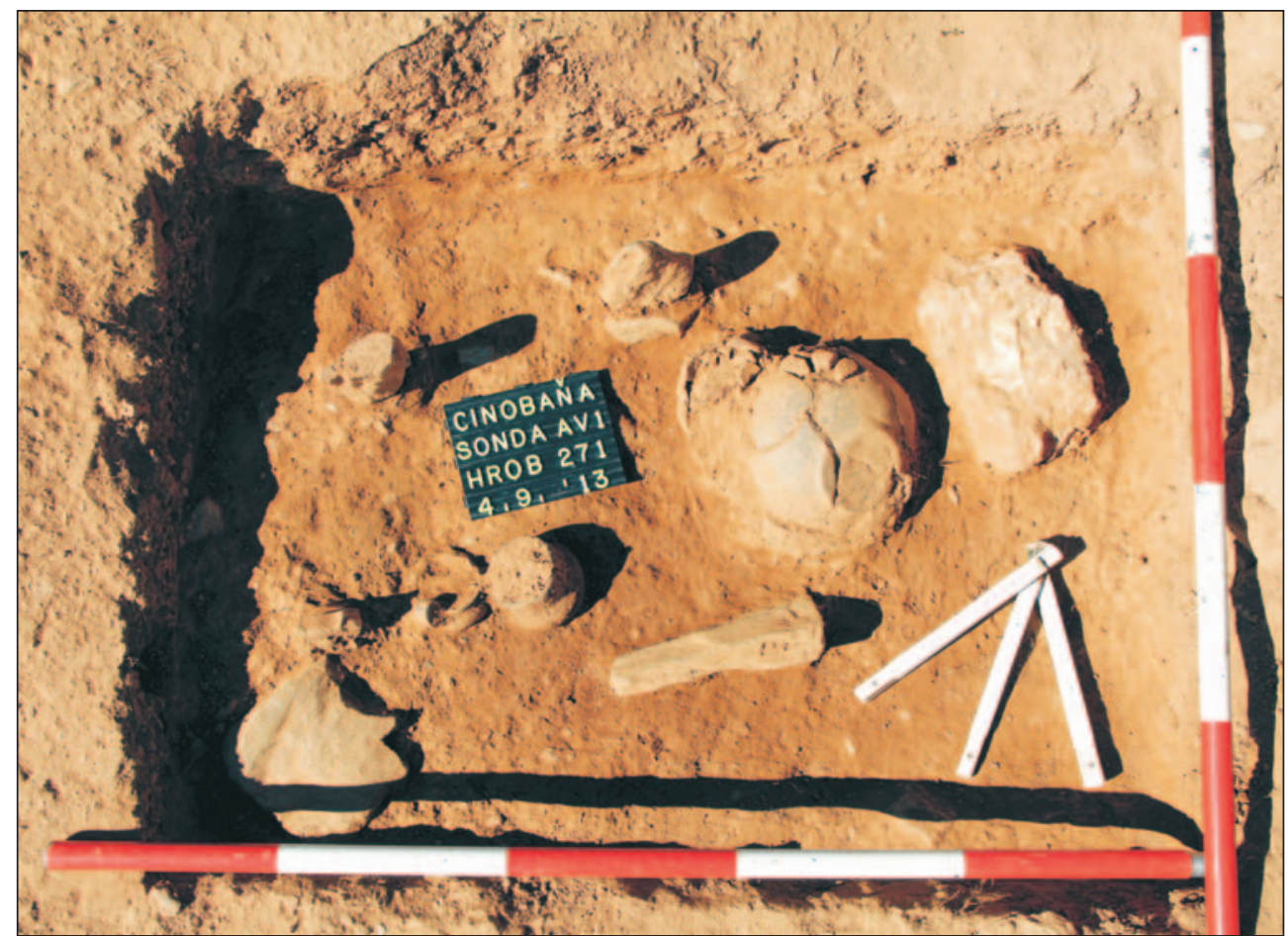

Obr. 7. Cinobaňa. Hrob 271/13. Foto V. Mitáš.

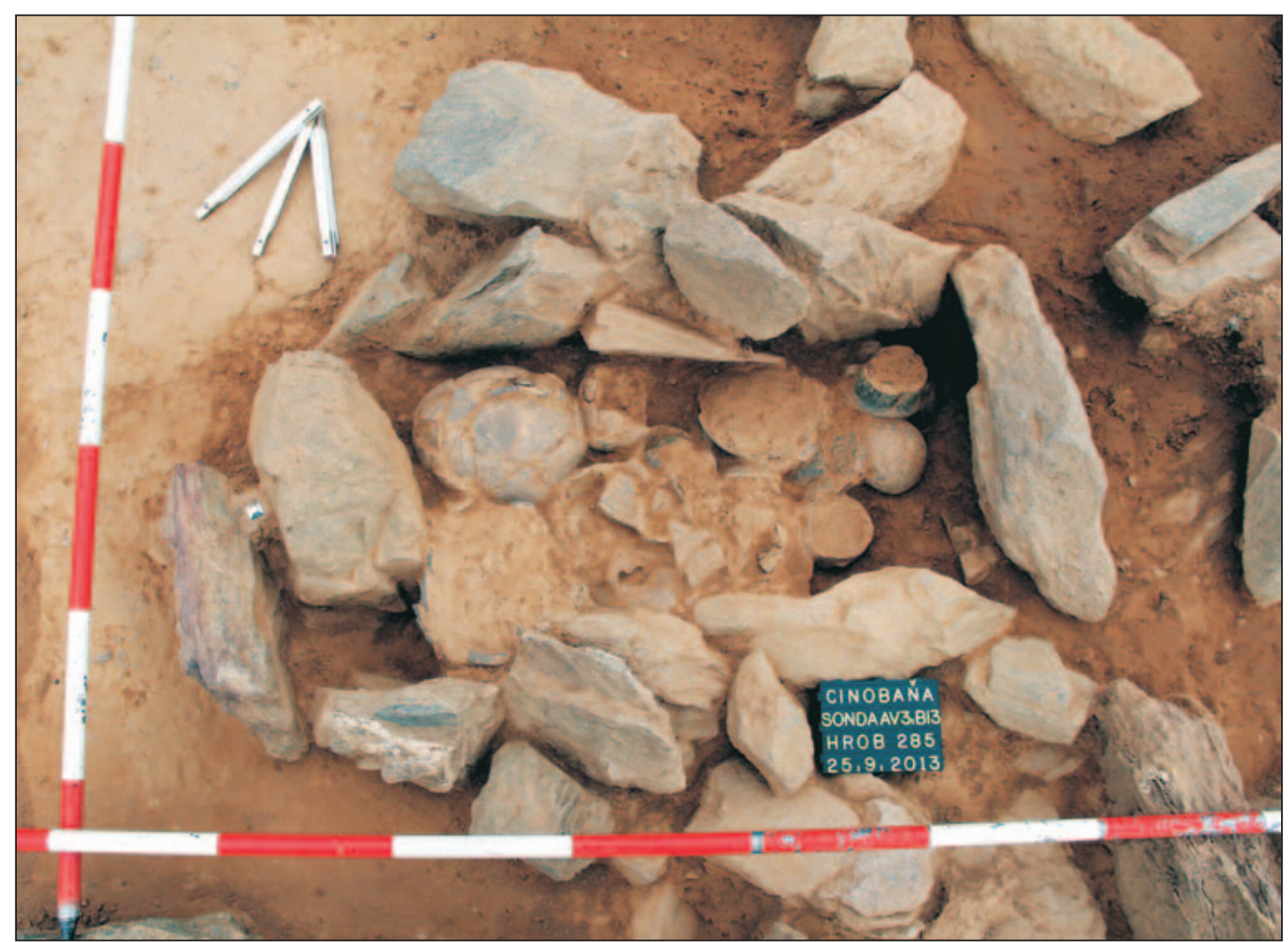

Obr. 8. Cinobaňa. Hrob 285/13. Foto V. Mitáš. 


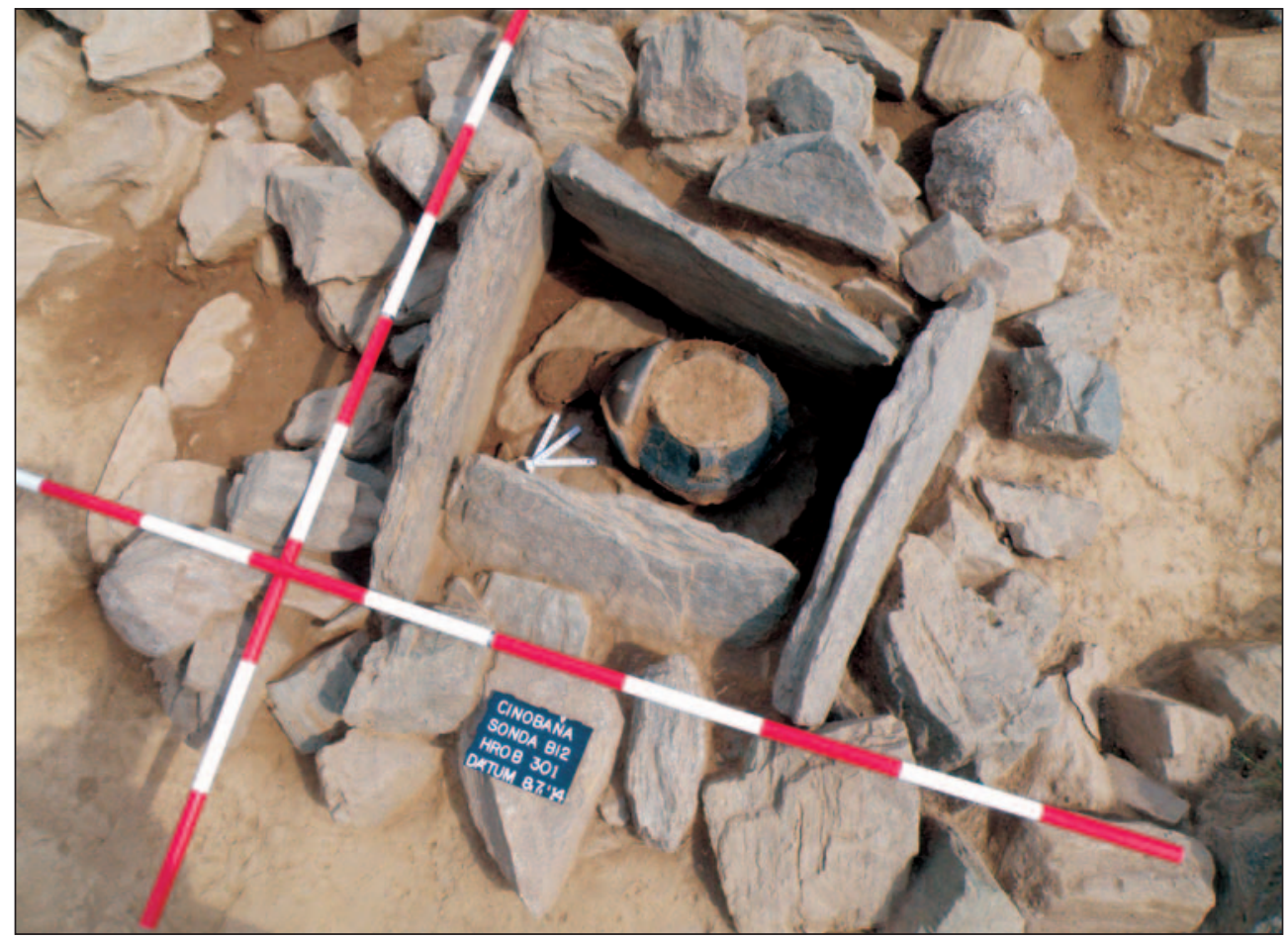

Obr. 9. Cinobaňa. Hrob 301/14. Foto D. Marková.

- Hrob 155/10 (obr. 4) - neskorá doba bronzová, kyjatická kultúra. Priestranná skrinka, ktorej obdížnikový pôdorys vyznačovali väčšie kamene. $V$ hrobe bolo 13 keramických nádob a zvyšky bronzových predmetov. Kremačné zvyšky boli uložené do troch centrálnych nádob, amfor (označených 1, 3, 11 a prekrytých misami 2, 4, 12), poprípade d’alších nádob menších tvarov, no boli tiež rozsypané medzi nádobami, prevažne vo východnej časti hrobu. V hrobe boli prítomné i zlomky bronzových predmetov. Z amfory (nádoby 3) pochádza zrno jačmeňa siateho nahozrnového (Hordeum vulgare var. coeleste).

- Hrob 235/12 (obr. 5) - mladá doba bronzová, pilinská kultúra. Urnový hrob pod kameňmi. Kremačné zvyšky boli uložené v urne (nádoba 1), ktorú zakrývala profilovaná misa (nádoba 2). Z urny pochádza nález semena hrachu siateho (Pisum sativum). Od severozápadu bola k urne priložená menšia amfora. Juhozápadne od urny boli spozorované drobné uhlíky.

- Hrob 265/13 (obr. 6) - neskorá doba bronzová, kyjatická kultúra. Hrob v naznačenej kamennej skrinke prekrytý kameňmi, resp. pod príkrovom. Hrobový celok s nadštandardným počtom keramických nádob, vyše 20, z ktorých väčšinu možno charakterizovat ako „keramické“ prílohy. V strede hrobu stála tzv. centrálna nádoba (označená 1), pri ktorej sa našli spálené kosti. Kremačné zvyšky sa zistili aj v d’alších nádobách, ale aj okolo nich. Identifikované semeno hrachu siateho (Pisum sativum) bolo odobraté z pokrievky (nádoba 21 s objemom hliny 2,5 l), prekrytej torzom nádoby vo východnej časti skrinky.

- Hrob 271/13 (obr. 7) - mladá/neskorá doba bronzová, kyjatická kultúra. Hrob s plytkou hrobovou jamou obdížnikového tvaru, ktorú vyznačovali menšie kamene. V nej uložený keramický inventár pozostával z piatich nádob. V menšej amfore (nádoba 3) bolo zistené semeno prosa siateho (Panicum miliaceum). Spálené l'udské kosti boli roztrúsené okolo nádob (najmä okolo nádoby 1), zhruba v strede hrobovej jamy.

- Hrob 285/13 (obr. 8) - neskorá doba bronzová, kyjatická kultúra. Hrobová jama tvaru obdížnika bola obložená väčšími kameňmi a čiastočne prekrytá kamennými platňami alebo menšími kameňmi. Ďalší hrob s nadštandardným počtom keramiky, bolo v ňom vyše 20 kusov. Spálené ludské kosti spolu s nerekonštruovatelným bronzovým predmetom sa nachádzali v amfore (nádoba 1) prekrytej misou (nádoba 2), prípadne v d’alších keramických urnách, ale i roztrúsené na dne hrobovej jamy. Semeno hrachu siateho (Pisum sativum) sa našlo v hrnci s pokrievkou (nádoba 19 a 20).

- Hrob 301/14 (obr. 9) - mladá doba bronzová, kyjatická kultúra. Skrinkový hrob s kamenným vencom. Keramický inventár uložený na kamennej platni zastupovalo pät’ nádob. V strede hrobovej jamy stála centrálna nádoba, urna (nádoba 1), pôvodne asi zakrytá misou, okolo boli menšie keramické prílohy. Preplavením hlinitého obsahu urny sa získalo semeno hrachu siateho (Pisum sativum). 


\section{METÓDY ARCHEOBOTANICKEJ ANALÝZY HODNOTENÝCH HROBOV}

\section{Stratégia odberu vzoriek v teréne}

Generálne sa analyzovali preplavené výplne keramických nádob s dominantným podielom hliny, $\mathrm{v}$ našom prípade vybraté z vyššie opísaných žiarových hrobov, prípadne aj uhlíky. Vzorkovanie od začiatku výskumu sledovalo otázky, ktoré nedokázal zodpovedat iný, v minulosti získaný hrobový materiál z juhu stredného Slovenska, kde sa pozornost’ a metodika bádatelov viditel’ne sústredila najmä na extrakciu a determináciu driev, uhlíkov (Hajnalová E. 1978a, 125).

V prípade hodnotených hrobových celkov sa použila stratégia cieleného, ale selektívneho vzorkovania (angl. judgement sampling strategy - Jones 1991), v rámci ktorej sa vzorky odoberali iba z výplní dobre (najmä kompaktne) uchovaných nádob, t. j. z istých častí hrobových celkov. Táto stratégia bola uplatnená aj pri zhromaždení súboru vzoriek uhlíkov, vyzdvihnutých ručne priamo z hrobových kontextov počas výskumu. Vyhodnotenie uhlíkov nie je súčastou tohto príspevku.

\section{Extrakcia rastlinného materiálu}

Preplavovacia stanica bola umiestnená na výskumnej základni v Cinobani ned’aleko od lokality. Uloženiny sa preplavovali súbežne s terénnym archeologickým výskumom. Rastlinné makrozvyšky sa zo sedimentov archeobotanických vzoriek extrahovali metódou manuálnej flotácie v celom objeme s použitím štandardných kalibrovaných sít vel'kosti 10; 0,5; 0,125 mm (Hajnalová M./Hajnalová E. 1998). Preplavovalo sa pitnou vodou z miestnej studne.

\section{Postup manuálneho preplavovania vzoriek}

1. Objem pôvodnej uloženiny určenej na preplavovanie sa odmeral $\mathrm{v}$ kalibrovaných nádobách. Spolu s dalšími informáciami o vzorke (objekt, dátum, popis nálezu a pod.) sa zaznamenal do archeobotanického denníka.

2. Pri menších objemoch (menej ako 1 liter) sa nasypala celá vzorka, pri väčších objemoch iba jej čast̉ do dostatočne vel'kej nádoby (vedra) a zaliala sa vodou. Nasledovalo jemné, niekol'konásobné premiešanie vzorky a opatrné zliatie lahkej frakcie (t. j. toho, čo vyplávalo na povrch) cez sústavu sít. Postup zaliatia uloženiny vodou, premiešania a zliatia cez sito sa opakoval, pokial' už žiadne nálezy neplávali. Frakcia zachytená na site sa následne premyla čistou vodou. Vo vybraných prípadoch sa uvedený proces fotograficky dokumentoval (obr. 10).

3. Podiely z preplavovacích sít sa zbalili do papierových obrúskov, opatrili sa štítkom a nechali na základni dosušit.

4. Dôkladne vysušené podiely sa prebalili do umelohmotných vrecúšok a označili.

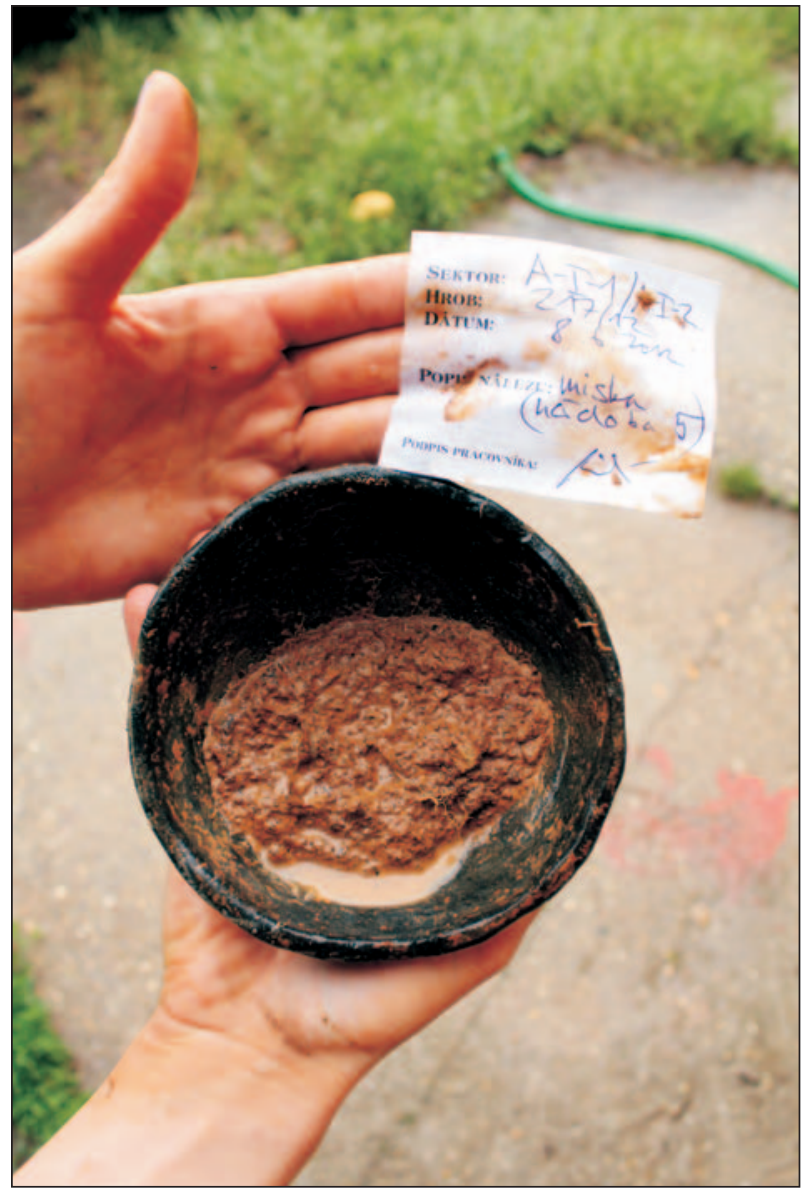

Obr. 10. Hrobová keramika v procese preplavovania. Foto V. Mitáš. 
5. Ťažká frakcia (zostatok materiálu na dne vedra) sa premyla cez sitá s vel'kostou 10 a $0,5 \mathrm{~mm}$. Na sitách sa vysušila. Nálezy z łažkej frakcie sa vyberali ručne (úlomky keramiky, osteologický materiál, zlomky bronzových predmetov, sklené koráliky a iné artefakty).

\section{Metóda laboratórnej analýzy}

Laboratórnej analýze v AÚ SAV boli podrobené všetky preplavené frakcie aj všetky samostatne odobraté vzorky uhlíkov.

1. Po evidencii vzoriek do prírastkového katalógu, v ktorom sa každej vzorke pridelilo špecifické archeobotanické číslo, boli informácie z terénneho výskumu k danej vzorke prepísané do laboratórneho protokolu.

2. Z preplavených frakcií sa pod binokulárnou stereoskopickou lupou Zeiss a Jenavert s maximálnym zväššením 40x vytriedili všetky zuholnatené a nezuholnatené semená a uhlíky, ale aj ulity slimákov či úlomky (ludských a zvieracích) spálených kostí. Rastlinné makrozvyšky sa následne druhovo determinovali a kvantifikovali. Ostatné nálezy sa zaznamenali do protokolu, zabalili a poskytli na d’alšiu analýzu, prípadne uložili v depozitári.

3. Pre taxonomickú determináciu semien bola využitá stereoskopická lupa Zeiss Discovery V 12, pre určenie uhlíkov stereoskopická lupou Zeiss a Jenavert s maximálnym zväčšením 250x. Vybrané nálezy sa dokumentovali aj (mikro)fotograficky.

4. Určené semená a uhlíky boli zabalené, označené ako spracované a sú uložené v archeobotanickom depozitári AÚ SAV v Nitre.

\section{Identifikácia rastlinných makrozvyškov}

Pri identifikácii rastlinných makrozvyškov, determinácii generatívnej časti rastliny a jej taxonomického určenia, boli použité kritériá vytvorené na základe podobností a rozdielov v morfológii - štruktúre, textúre a rozmeroch rastlinných diaspór. Podla klúča, ktorý vypracovala S. Jacomet (2006), boli určované obilné zrná. ${ }^{2}$ Výsledky archeobotanických analýz z jednotlivých sezón sú uvedené vo výskumných správach, ktoré sú uložené v dokumentácii Archeologického ústavu SAV (Mihályiová 2009; 2010a; 2010b; 2010c; 2014; 2015a; 2017).

\section{KRITÉRIA K URČOVANIU OBILNÝCH ZŔN A SEMIEN STRUKOVÍN}

\section{Obilniny}

Botanicky patria k jednoročným trávam z čelade lipnicovitých (Poaceae). Pestujú sa pre vel’ké semená, zrná s obsahom uhlohydrátov a niektoré aj s vyšším obsahom bielkovín. Sú bohatým zdrojom energie. Zrno je možné skladovat bez ujmy na kvalite dlhšiu dobu. Zo zrna sa melie múka, lámu krúpy, varia kaše, pečú placky, posúchy a chlieb (Hajnalová E. 1999, 19).

- Jačmeň siaty (Hordeum vulgare) má zrno symetricky vypuklé na ventrálnej aj dorzálnej strane, zužujúcim sa smerom k apexu a báze (obr. 11: 1). Ďalším dôležitým rozlišovacím znakom je široká a plytká ventrálna ryha (Jacomet 2006). Jačmeň zastupuje viacero typov a to podla počtu fertilných zín na klasovom vretene: jačmeň dvojradový, štvorradový a šestradový. U jačmeňa dvojradového (Hordeum vulgare subsp. distichon, syn. Hordeum distichon) je vyvinutý len jeden klások, resp. stredové zrno na jednom článku klasového vretena, ostatné dva bočné klásky sú nevyvinuté. Zrno je symetrické, rovné a netočené. V prípade jačmeňa šestradového (Hordeum vulgare subsp. vulgare, syn. Hordeum hexastichon) sú vyvinuté všetky tri zrná. Prostredné zrno je rovné a symetrické, podobné nálezom dvojradového

2 Určovanie planorastúcich druhov rastlín a drevín z hrobových kontextov v Cinobani sa robilo s použitím atlasov semien, plodov a driev/uhlíkov (Beijerinck 1947; Bojňanský/Farkašová 2007; Schermann 1967; Schweingruber 1978). Slovenské názvoslovie a ekológia rastlín sa opiera o atlasy a klúče (Červenka a kol. 1986; Dostál/Červenka 1991). 


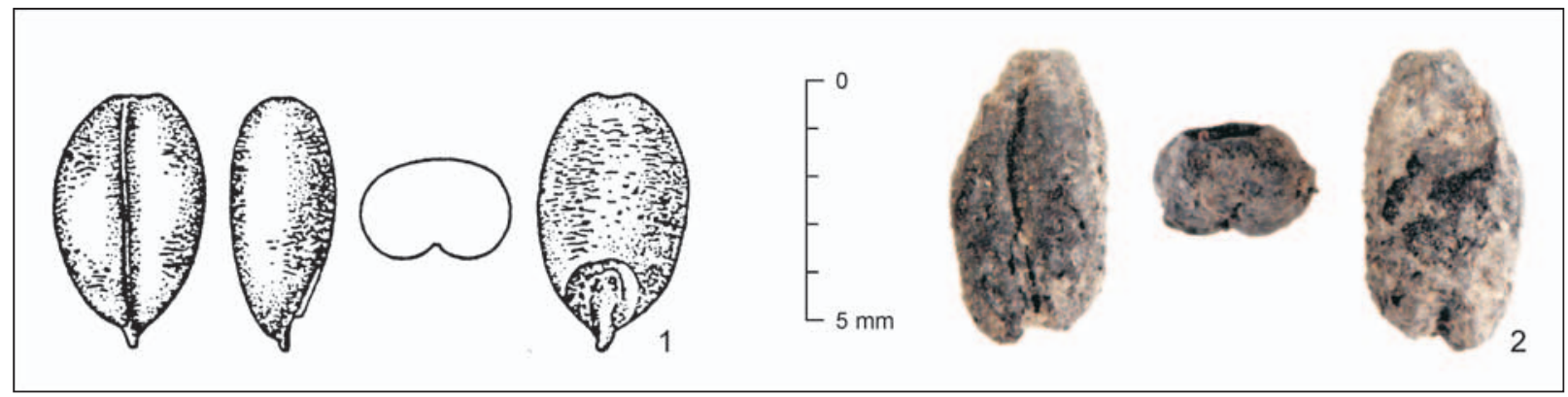

Obr. 11.1 - jačmeň siaty dvojradový nahý (Hordeum distichon var. nudum; kresba podla Jacomet 2006); 2 - nález zrna jačmeňa siateho nahozrnového (Hordeum vulgare var. coeleste) z pohrebiska v Cinobani (foto J. Mihályiová).

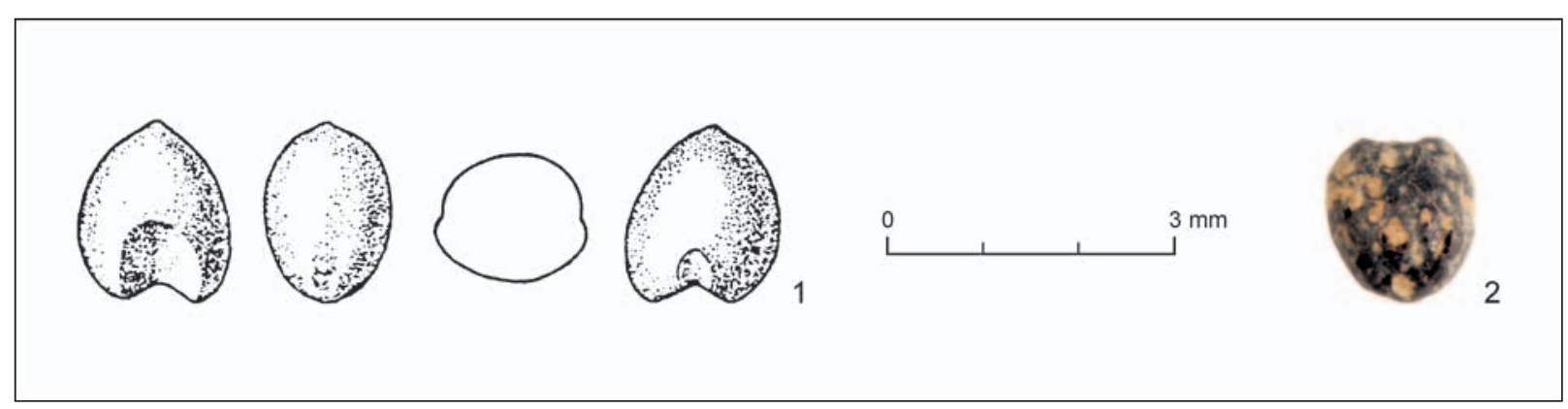

Obr. 12. 1 - proso siate (Panicum miliaceum; kresba podla Jacomet 2006); 2 - nález z pohrebiska v Cinobani (foto J. Mihályiová).

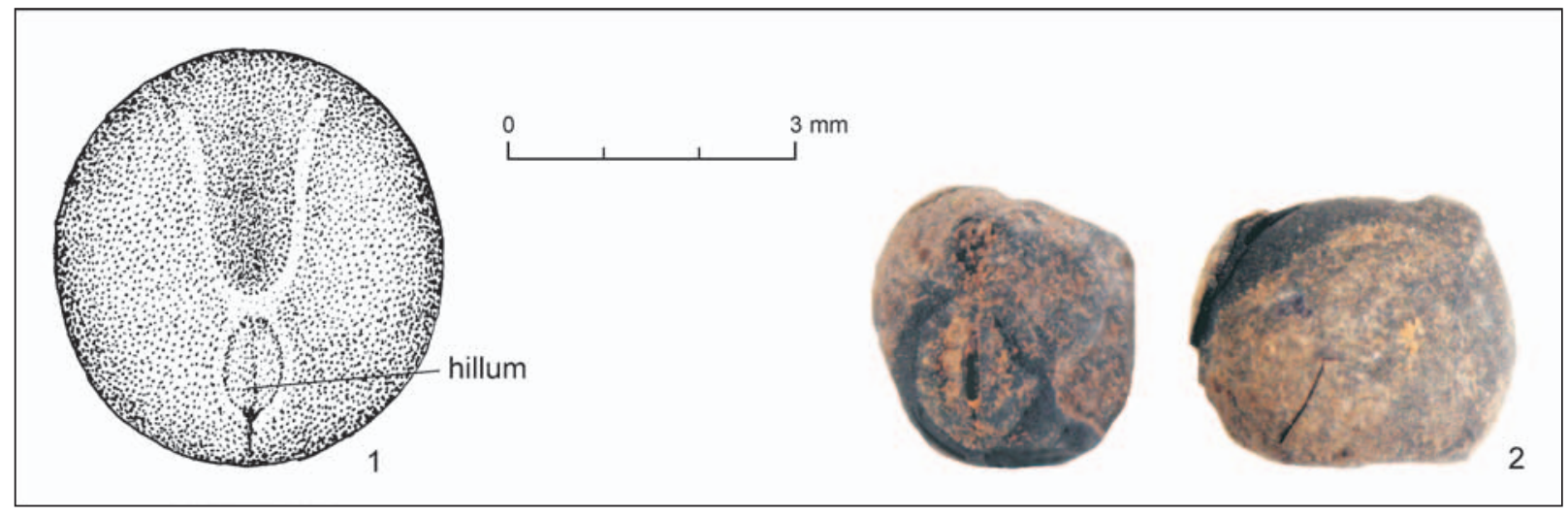

Obr. 13. 1 - hrach siaty (Pisum sativum; kresba podla Bojňanský/Farkašová 2007); 2 - nález z pohrebiska v Cinobani (foto J. Mihályiová).

jačmeňa, bočné zrná sú stočené doprava alebo dolava. Počítaním pomeru priamych a stočených zŕn v pomere 1:2 možno (hypoteticky) stanovit, či sa vo vzorke nachádza dvojradový, alebo šestradový jačmeň, prípadne oba druhy (Jacomet 2006).

U oboch typov jačmeňa je možné archeobotanicky rozlíšit nahé a plevnaté formy označované ako var. coeleste (ak ide o nahý jačmeň dvojradový) a var. nudum (ak ide o nahý jačmeň šestradový). Plevnaté jačmene sa vyznačujú výrazne zúženými koncami, tak na apexe, ako aj na báze, a pozdĺžnymi vystupujúcimi lištami na ventrálnej a dorzálnej strane zrna. Zrno je v priereze hranaté. Nahé formy sú na rozdiel od plevnatých jačmeňov viac zaoblené, apex je výrazne tupý, nakol'ko lišty absentujú. Zrno nahého jačmeňa je v priereze okrúhle. Na povrchovej štruktúre sú viditelné horizontálne zvl- 
nené línie (Jacomet 2006). Nález zrna jačmeňa z Cinobane bol determinovaný bližšie ako jačmeň nahý (obr. 11: 2). Na základe jedného zrna nie je možné rozhodnút, či ide o jačmeň dvojradový alebo viacradový.

Možno dodat, že jačmeň siaty (Hordeum vulgare) je známy skôr ako nechlebová obilnina. Väčšinou sa konzumuje vo forme krúpových kaší, polievok a posúchov. Okrem toho je ho možné použit aj na výrobu piva, čo má vel’mi dlhú históriu (Hajnalová E. 1993, 72-75; Stika 2011). Taktiež je dôležitým krmivom domácich zvierat. Ide o ekologicky nenáročnú obilninu.

- Proso siate (Panicum miliaceum) spravidla nepresahuje vel'kost’ $2 \mathrm{~mm}$. Má zrná oválneho až okrúhleho tvaru a špecifický typ embrya, ktoré môže niekedy absentovat', pričom sa na zrne vytvára typická priehlbina (obr. 12: 1). Embryo prosa siateho alebo preliačina po ňom je velmi široká s rozbiehajúcimi sa okrajmi a zasahuje takmer do polovice zrna (Jacomet 2006). Nález z Cinobane (obr. 12: 2) má stále zachované embryo.

V súčasnosti je proso siate (Panicum miliaceum), d’alšia ekologicky nenáročná obilnina, podceňovaná až nepoznaná plodina. Velmi dobre znáša extrémne vysoké teploty, pôdy chudobné na živiny ako aj dlhodobejšie suchá. Dajú sa z nej však pripravit rôzne pečené a varené múčne jedlá (Hajnalová E. 1993, 91, 92). Celkovo by sa tento obilný druh mohol klasifikovat ako najodolnejší voči všetkým nepriaznivým klimatickým okolnostiam a podmienkam. Aj preto sa $\mathrm{v}$ súčasnosti pestuje $\mathrm{v}$ Rusku, východnej Ázii a na Blízkom Východe. Má krátky vegetačný cyklus a dozrieva už za 60-90 dní (Hajnalová E. 1993, 91, 92; Hajnalová M. 2012, 80).

\section{Strukoviny}

Sú jednoročné rastliny z čelade vikovitých (Fabaceae). Na poliach sú spoločníkmi zrnovín a často sa pestujú v záhradách ako zelenina. Ich semená majú rovnakú morfologickú charakteristiku. Diagnostickými prvkami pre druhovú klasifikáciu strukovín (Fabaceae) sú vel'kost’ a tvar semena, no zásadným určovacím kritériom je dížka a tvar hillum (Anderberg 1994). Strukoviny možno v kuchyni mnohostranne využit. Konzumujú sa čerstvé, ale môžu sa i sušit a dlhodobo skladovat.

- Hrach siaty (Pisum sativum) dosahuje vel'kosṫ 6-8 x 6-7,5 mm (obr. 13: 1). Má okrúhle, až valcovité a krátke hillum nepresahujúce štvrtinu obvodu semena (Anderberg 1994, 52). Nálezy z Cinobane boli determinované najmä na základe vel'kosti, pravidelného gulovitého tvaru. Hillum bolo prítomné iba na jednom náleze (obr. 13: 2).

Hrach siaty zastupuje $\mathrm{v}$ nálezoch $\mathrm{z}$ doby bronzovej $\mathrm{v}$ Karpatskej kotline popredné miesto medzi strukovinami (Stika/Heiss 2013b, 355, tab. 19.5). Zo začiatku sa na prípravu pokrmov používali len jeho dokonale vyzreté a suché semená. Nezrelé a ovel’a sladšie semená hrachu sa začali konzumovat' až v novoveku. V období nedostatku obilnín sa mlel na múku. Najčastejšie sa z neho pripravovali kaše a polievky. Jedlá z hrachu sa bežne konzumovali, poprípade boli dôležitými obradnými pokrmami. ${ }^{3}$

\section{VÝSLEDKY}

Počas siedmich rokov výskumu pohrebiska v Cinobani sa z 216 hrobových celkov odobralo spolu 730 archeobotanických vzoriek. Z toho 519 vzoriek pochádza z preplavených obsahov nádob o celkovom objeme preplavenej hliny 775 l. Celkový počet nálezov zuholnatených rastlinných makrozvyškov získaných preplavením, ktoré zahŕňajú 26 botanických taxónov, je 4730 . Väčšinu nálezov predstavujú uhlíky. ${ }^{4}$ V menšom počte sa determinovali zuhol'natené i nezuhol'natené semená planorastúcich rastlín, ktoré sú publikované na inom mieste (Mihályiová 2015b).

Z pestovaných druhov rastlín boli v hrobových celkoch z Cinobane (tabela 1) identifikované dve zrná dvoch druhov obilnín, a to jačmeňa siateho nahozrnového (Hordeum vulgare var. coeleste) v hrobe 155/10 a prosa siateho (Panicum miliaceum) v hrobe 271/13. Obe obilné zrná sa našli v nádobách. Zo strukovín bol

3 http://ncpvat.cvtisr.sk/buxus/docs//Veda_v_CENTRE/VvC_2016/strukoviny.pdf

4 Okrem vzoriek hliny sa odoberali aj samostatné vzorky uhlíkov (209 za sedem sezón na lokalite), ale tieto vzorky v príspevku nehodnotíme. 


\begin{tabular}{|c|c|c|c|c|c|c|c|c|c|}
\hline 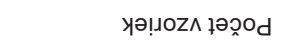 & m & n & $\nexists$ & $\dot{r}$ & - & ڤ & \multicolumn{3}{|c|}{0} \\
\hline exwęuzod & 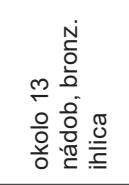 & 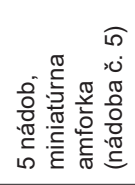 & 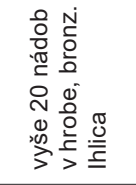 & 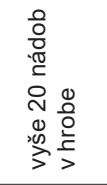 & 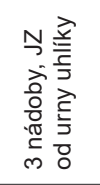 & $\begin{array}{l}\frac{0}{0} \\
.0 \\
0 \\
0 \\
60 \\
\frac{0}{8} \\
\frac{0}{0}\end{array}$ & \multicolumn{3}{|c|}{ 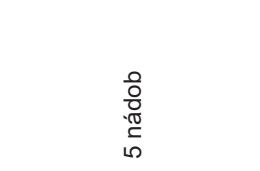 } \\
\hline әІчемлоңео & 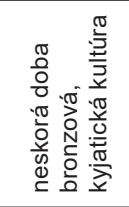 & 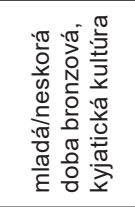 & 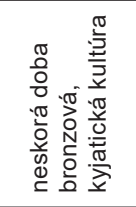 & 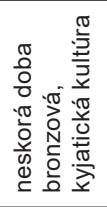 & 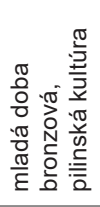 & 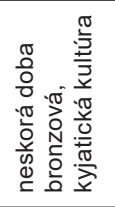 & \multicolumn{3}{|c|}{ 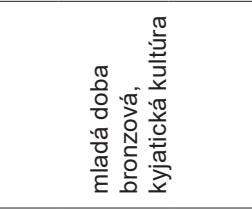 } \\
\hline 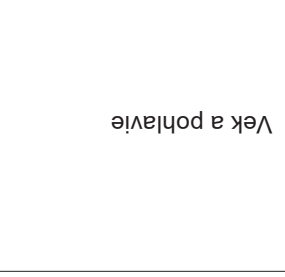 & 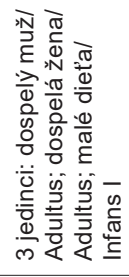 & 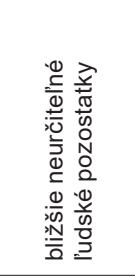 & 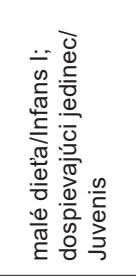 & 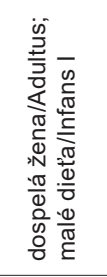 & 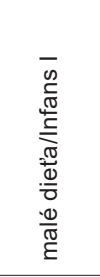 & 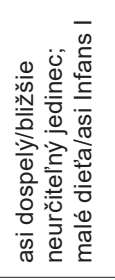 & \multicolumn{3}{|c|}{ 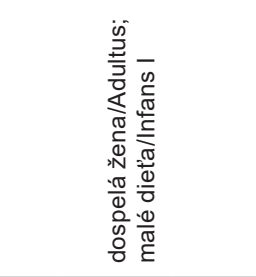 } \\
\hline 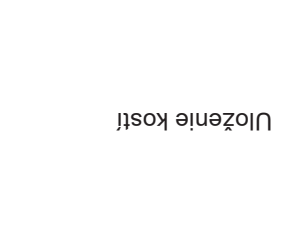 & 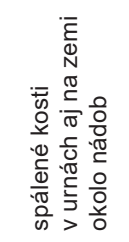 & 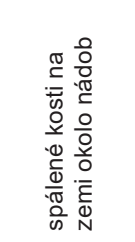 & 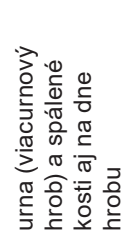 & 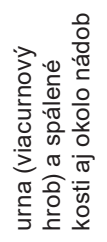 & $\stackrel{\widetilde{5}}{5}$ & 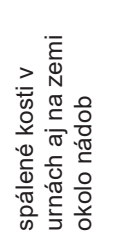 & \multicolumn{3}{|c|}{ 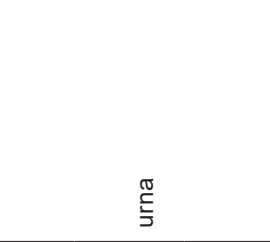 } \\
\hline пqолу емелd, & 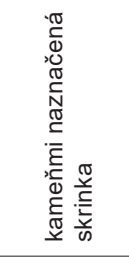 & 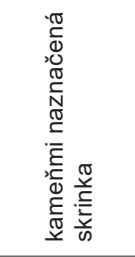 & 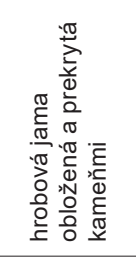 & 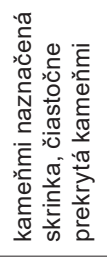 & 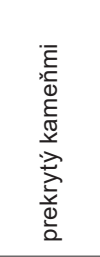 & 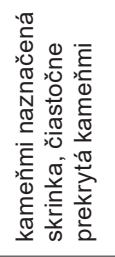 & \multicolumn{3}{|c|}{ 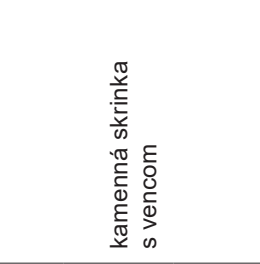 } \\
\hline Кqopẹu $\mathrm{d} \kappa_{\perp}$ & 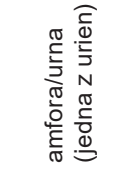 & 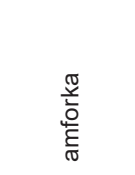 & 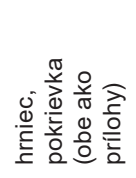 & 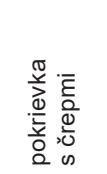 & 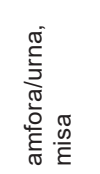 & 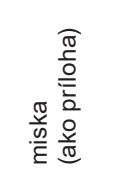 & \multicolumn{3}{|c|}{ 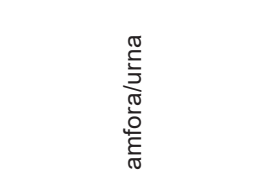 } \\
\hline o|s!? әqopẹu ^ ouəməS & $m$ & $m$ & $\begin{array}{l}\stackrel{N}{1} \\
\text { o) }\end{array}$ & $\bar{N}$ & $\stackrel{N}{=}$ & N & \multicolumn{3}{|c|}{-} \\
\hline 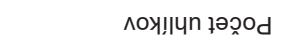 & 1 & r & r & 0 & م & n & 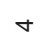 & N & - \\
\hline Ки!^әגа & 1 & 空 & 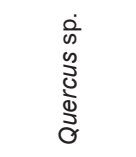 & $\begin{array}{l}\dot{0} \\
0 \\
0 \\
0 \\
0 \\
0 \\
0 \\
0\end{array}$ & $\begin{array}{l}\dot{0} \\
0 \\
0 \\
0 \\
0 \\
0 \\
0 \\
0\end{array}$ & 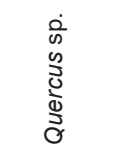 & 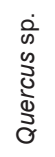 & 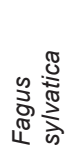 & 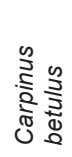 \\
\hline uə!யəs łəગ્રంd & - & - & - & - & - & - & \multicolumn{3}{|c|}{-} \\
\hline Sumnat & 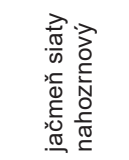 & $\begin{array}{l}\frac{0}{0} \\
\frac{\pi}{\omega} \\
0 \\
\frac{0}{0} \\
\frac{0}{2}\end{array}$ & \multicolumn{7}{|c|}{ 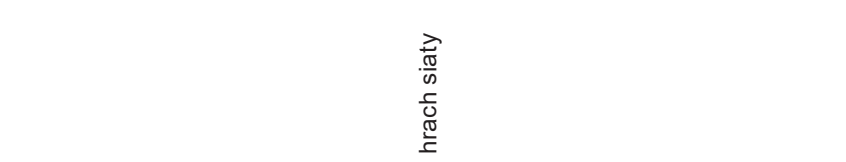 } \\
\hline & 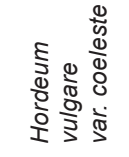 & 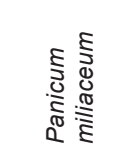 & \multicolumn{7}{|c|}{ 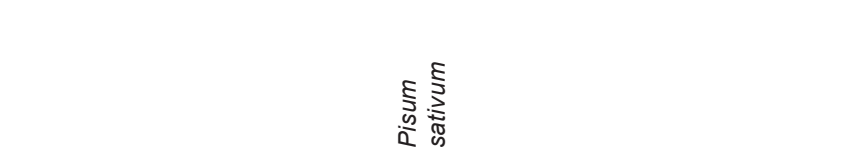 } \\
\hline qOגH & 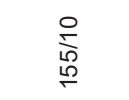 & $\underset{N}{\stackrel{m}{N}}$ & $\sum_{\substack{\infty \\
\stackrel{\infty}{\infty}}}^{\infty}$ & 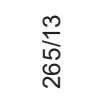 & $\underset{\substack{\sim \\
\sim}}{\stackrel{N}{N}}$ & 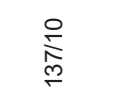 & \multicolumn{3}{|c|}{$\underset{⿱ 亠 䒑}{\stackrel{J}{े}}$} \\
\hline
\end{tabular}


determinovaný hrach siaty (Pisum sativum), po jednom semene v piatich hroboch (137/10, 235/12, 265/13, 285/13 a 301/14).

S ohl'adom na zdokumentovaný keramický inventár študovaných žiarových hrobov možno konštatovat', že hrach siaty bol objavený v miske/hrob 137/10 (obr. 14: 1), v urne prekrytej misou/hrob 235/12, v pokrievke prekrytej torzom nádoby/hrob 265/13 (obr. 6: 2), amfore prekrytej misou/hrob 285/13 a v urne zrejme pôvodne zakrytej misou/hrob 301/14. V preplavenom obsahu jednej z popolníc/amfory (obr. 14: 2) z hrobu 155/10 sa našlo zrno jačmeňa siateho nahozrnového a menšia amfora (obr. 14: 3) z hrobu 271/13 obsahovala semeno prosa siateho. Nádoby so zachovalými makrozvyškami pestovaných rastlín nie sú typologicky homogénnou skupinou: prevažujú amforovité tvary, ale sú tam tiež misy či pokrievka. Z funkčného hladiska to boli bud' urny ${ }^{5}$, alebo prílohy (obr. 14). V dvoch prípadoch sú v užšej analyzovanej skupine hroby z neskorej doby bronzovej s nadštandardným počtom keramických nádob, vyše 20 kusov (obr. 6; 8). Naznačuje to azda pomyselný „,vzt̉ah“, čím viac nádob v hrobe, tým vyššia úspešnost’ identifikovat’ makrozvyšok (aj) pestovanej rastliny v nálezovom celku? Každopádne však platí, že počet nálezov/druhová škála pestovaných rastlín sú pomerne nízke i napriek skutočnosti, že sa preskúmalo 314 hrobov (obr. 15), väčšina z nich bola archeobotanicky vzorkovaná a preplavilo sa 7751 hliny. Príčinou, prečo je v kvantitatívne obsiahlom súbore vzoriek z Cinobane všeobecne nízky počet rastlinných makrozvyškov, môžu byt aj miestne pôdne podmienky ${ }^{6}$, ktoré nie sú žičlivé pre uchovanie organických zvyškov.

\section{DISKUSIA}

Doba bronzová predstavuje éru praveku s relatívne vysokou úrovňou systému hospodárstva (Furmánek 2015, 273, 274) a premyslenými polnohospodárskymi stratégiami (Hajnalová M. 2012). Polnohospodárstvo doby bronzovej v širšom priestore Európy dokumentujú milióny makrozvyškov pestovaných rastlín (Stika/Heiss 2013a, 189, obr. 1), pochopitelne, že s regionálnymi diferenciami (Stika/Heiss 2013b, 364). Populácia doby popolnicových polí v kultúrnej krajine dokázatelne hospodárila na poliach, záhradách, pasienkoch, sadoch, ale aj v prilahlých lesoch a vodných plochách (Gyulai 2010, 127).

Podla poslednej súhrnnej štúdie (Hajnalová M. 2012, 128, 129, obr. 8: 6) sa v archeobotanických súboroch datovaných do mladej a neskorej doby bronzovej na území Slovenska objavuje predovšetkým nahozrnová pšenica siata (Triticum aestivum/turgidum/durum), proso siate (Panicum miliaceum) a pšenica špaldová (Triticum spelta), ktoré sú velmi často sprevádzané strukovinami ako hrach siaty (Pisum sativum), šošovica kuchynská (Lens culinaris) a bôb konský (Vicia faba). V menšom množstve sa objavuje pšenica jednozrnová (Triticum monococcum), pšenica dvojzrnová (Triticum dicoccum) a jačmeň siaty (Hordeum vulgare). Ojedinele sa evidujú aj zrná raže siatej (Secale cereale) a ovsa (Avena sp.; Hajnalová M. 2012, 47-66). Tento obraz sa líši od starších údajov, kde v nálezoch prevládala pšenica dvojzrnová a jačmeň (Hajnalová E. 1993, 72-75).

Väčšinu dokladov o pestovaní jačmeňa siateho, jačmeňa siateho var. nahozrnového a hrachu siateho v dobe popolnicových polí na území Slovenska poskytli výskumy sídlisk a hradísk, Dolný Kubín (Hajnalová E. 1976), Ilija-Sitno (Hajnalová E. 1985; 1990), Pobedim-Hradištia (Studeníková/Paulík 1983; Tempír 1969) a d’alšie (Hajnalová E. 1994, tab. 1, 3). Zo Zemplínskych Kopčian na východnom Slovensku pochádza sídliskový nález pravdepodobne umelo drvených zŕn jačmeňa siateho nahozrnového (Hordeum vulgare var. Coeleste; Hajnalová E. 1993, 74). Od strednej doby bronzovej bolo zámerne pestované na území Slovenska tiež proso siate (Hajnalová M. 2012, 80). Trojica bližšie sledovaných a na pohrebisku v Cinobani zidentifikovaných pestovaných rastlín bola prítomná a viacpočetne zastúpená aj na sídlisku lužickej kultúry v lokalite Hajná Nová Ves-Lúky (Hajnalová M. 2013, 135, 136, obr. 195; Wiedermann 2013) alebo na hradisku lužickej kultúry na lokalite Zemianske Podhradie-Hradištia (Hajnalová E./ Poláčik 1999, tab. 1).

\footnotetext{
5 Podla antropologickej analýzy J. Pavelkovej boli vo vybraných urnách jedinci rôzneho veku a pohlavia. Za informáciu jej kolegiálne d'akujeme.

6 Pôdny typ lokality - kambizem kyslá. Pedologickú analýzu vyhotovil v roku 2008 J. Hraško. Je súčastou výskumnej dokumentácie z prvej výskumnej sezóny pohrebiska v Cinobani.
} 

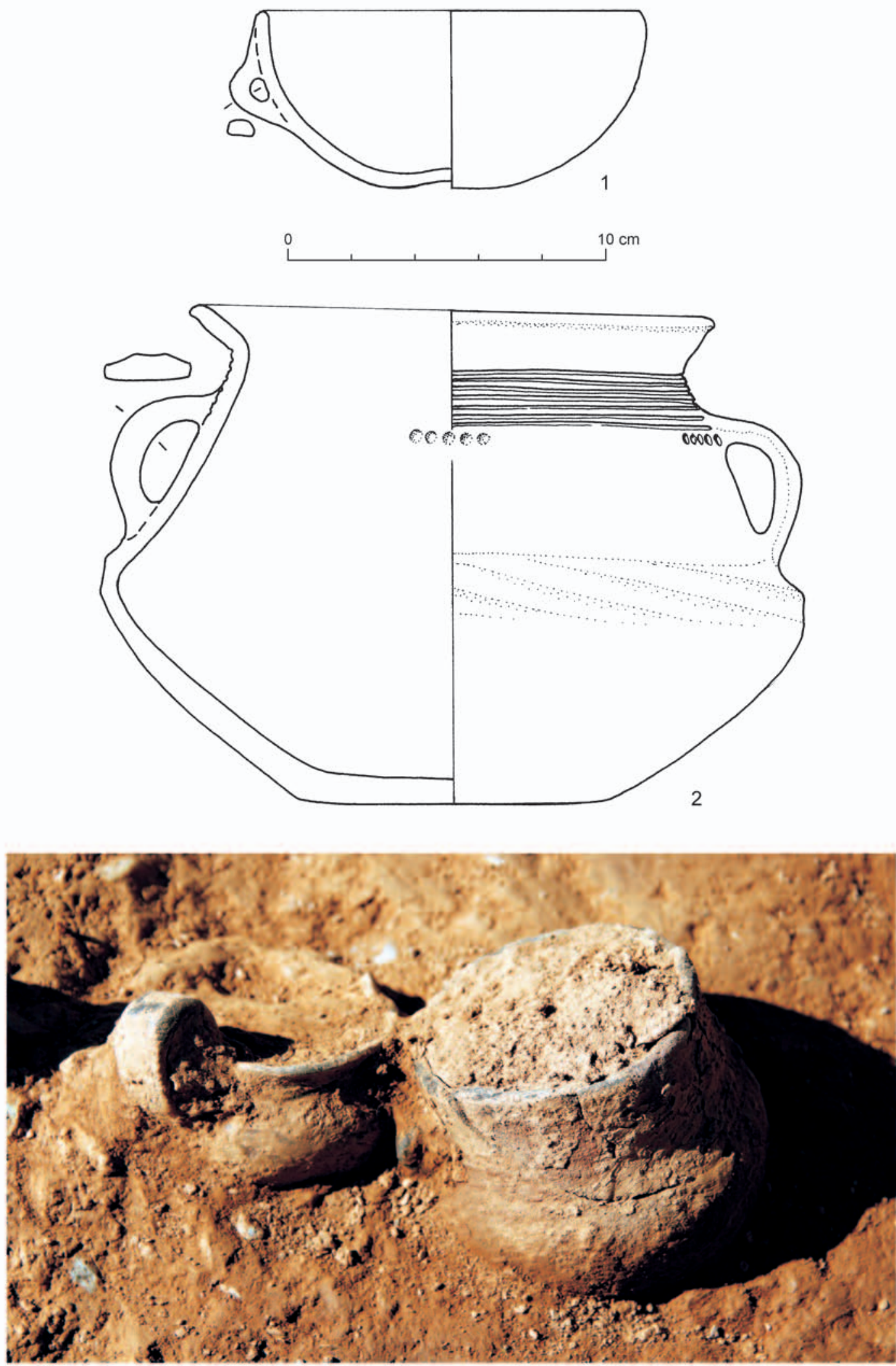

Obr. 14. Cinobaňa. 1 - misa kyjatickej kultúry s archeobotanickým nálezom Pisum sativum; 2 - amfora kyjatickej kultúry s archeobotanickým nálezom Hordeum vulgare var. coeleste; 3 - amforka kyjatickej kultúry s archeobotanickým nálezom Panicum miliaceum. Kresba Z. Nagyová, foto V. Mitáš. 


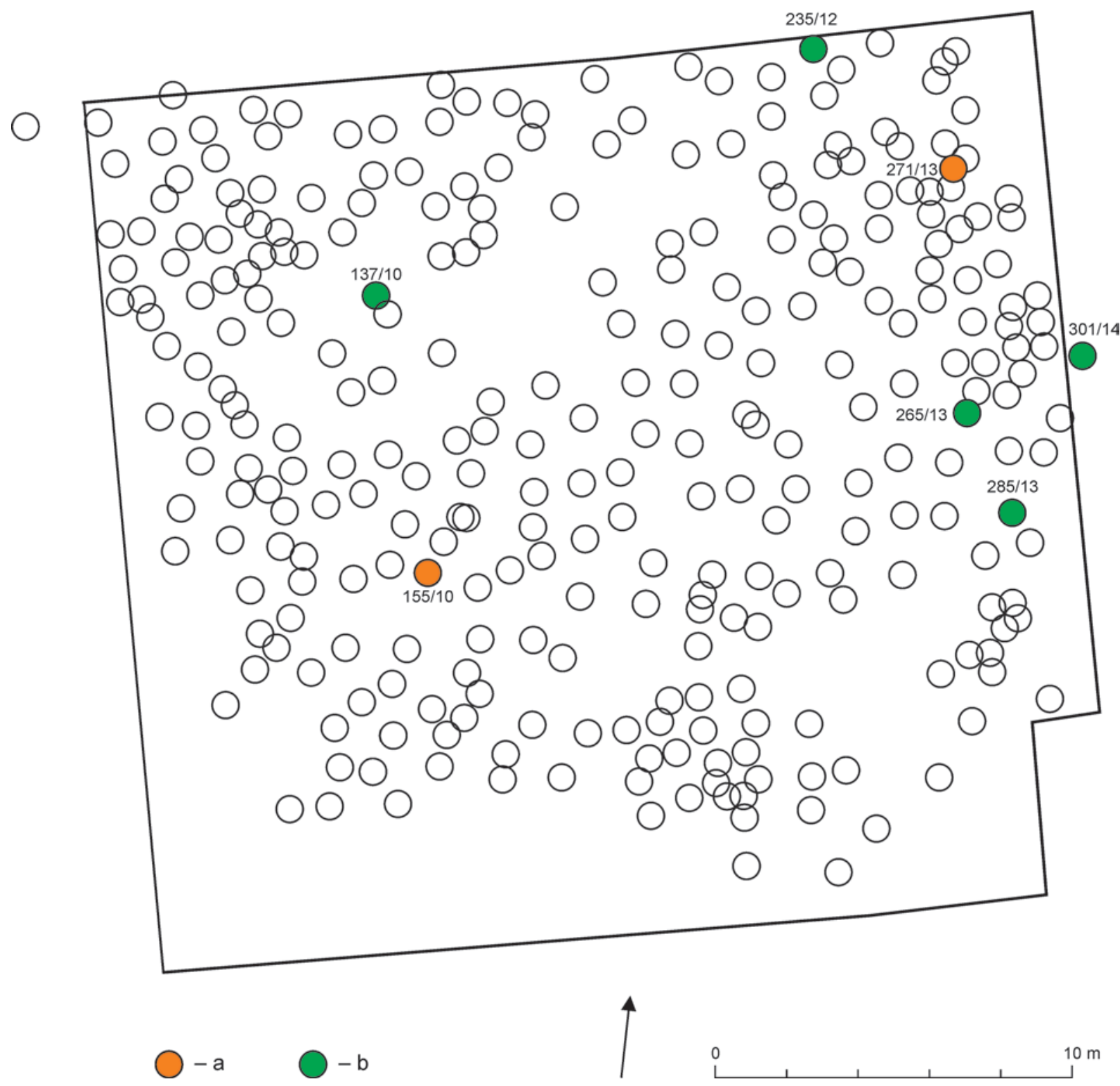

Obr. 15. Cinobaňa. Lokalizácia nálezov makrozvyškov pestovaných rastlín na preskúmanej ploche pohrebiska. Legenda: a - obilniny; b - strukoviny. Plán V. Mitáš.

\section{Archeobotanika na pohrebiskách}

Doterajšie archeobotanické poznatky z pohrebísk z doby popolnicových polí na Slovensku predstavujú takmer výhradne informácie o drevinách/uhlíkoch z výplní keramických nádob (urien) alebo z ich blízkeho okolia, prípadne zo žiaroviska (Hajnalová E. 1978a, 124-125; 1978b).

Archeobotanické údaje pochádzajú z pohrebiska lužickej kultúry v Diviakoch nad Nitricou, pohrebiska kultúry Suciu de Sus v Zemplínskych Kopčanoch, pohrebiska lužickej kultúry v obci Medovarce alebo k Cinobani kultúrne príbuzného a teritoriálne ned’alekého pohrebiska v Radzovciach (Furmánek/Mitáš 2010b, 39-42, 91, 92; Hajnalová E. 1978a, 124-125). Novšie publikované archeobotanické dáta sú z pohrebísk lužickej kultúry, napr. Zvolen, čast̉ Balkán a Žiar nad Hronom (Hajnalová E./Hajnalová M./Mihályiová 2003, 49; Mihályiová/Zachar 2016, 175). Uhlíky z iných pohrebísk poskytli bohatší sortiment drevín ako Cinobaňa. Môže to odzrkadlovat rozličné geografické, pôdne a vegetačné podmienky preskúmaných lokalít, ale aj lokálne špecifiká pohrebného rítu. Podobne ako v Cinobani aj na ostatných lokalitách však bol prevládajúcou drevinou dub (Quercus sp.). 


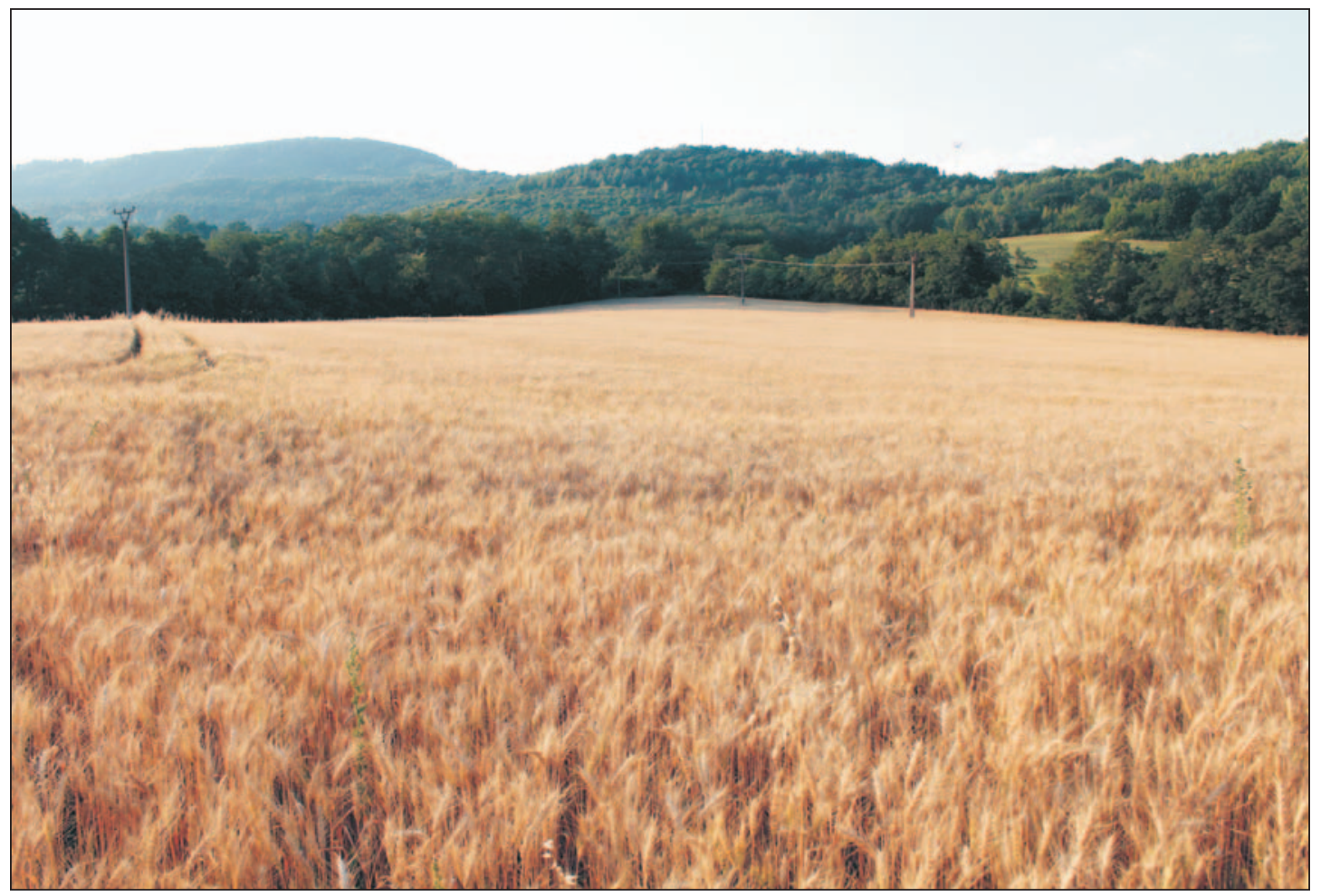

Obr. 16. Cinobaňa. Polnohospodárske využitie miesta sídliska v súčasnosti. Foto V. Mitáš.

Len pohrebisko v Medovarciach by bolo výnimkou, kde je prítomný brest (Ulmus sp.). V tomto prípade uhlíky pochádzajú iba z jedného hrobu (nie však z výplne nádoby) a navyše tento súbor ani vzorka nie sú reprezentatívne (Hajnalová E. 1978a, 124).

Jedinou publikovanou lokalitou zo Slovenska, kde sa podobne ako v Cinobani preplavili vybrané obsahy nádob, avšak $\mathrm{v}$ omnoho menšom počte kusov, je pohrebisko lužickej kultúry v Ilave-Porubskej doline (Hajnalová M./Katkinová 2002). Na tejto lokalite sa z rastlinných makrozvyškov prislúchajúcich plodinám zistili z obilnín vidlička pšenice (Triticum sp.), bližšie neidentifikované zrno obilniny (Cerealia indet.) ako aj iné zvyšky po obilninách, napr. úlomky stebiel (slamy). Zo strukovín to bolo neúplné semeno hrachu siateho (Pisum sativum; Hajnalová M./Katkinová 2002, 23, tab. 1). Tzv. vidlička je zvyškom kláskov plevnatých druhov zrnovín. Pozostáva z článku kláskového vretena, teda lôžka, kde boli na rastlinu prirastené zrná a zo spodnej časti kláskových prípadne kvetných pliev. Ich vel'kost' sa pohybuje pod $1 \mathrm{~mm}$. Sú pre rozlišovanie jednotlivých druhov obilnín rovnako dôležité ako zrno.

Z východnej časti Mad’arska, ktorá kultúrne priamo súvisí s teritóriom kultúrneho komplexu juhovýchodných popolnicových polí, v súčasnosti neexistuje relevantný archeobotanický materiál zo žiarových pohrebísk pilinskej a kyjatickej kultúry (Gyulai 2010, 110-111, 127-134), ktorý by bolo možné komparovat’ s nálezmi z Cinobane. Nové dáta a z nich vyvstávajúce obohacujúce poznatky $\mathrm{k}$ riešeniu otázok pohrebného rítu mladej doby bronzovej pribúdajú do archeobotanickej databázy skôr zo západnejšie situovaných lokalít, napr. z územia Moravy (Parma a i. 2016, 310-314; Parma a kol. 2017).

Zo súčasného štúdia pohrebísk z mladej a neskorej doby bronzovej na Slovensku vyplýva, že poskytujú dôkazy relatívne nízkeho počtu makrozvyškov pestovaných rastlín, ktoré sa dostali do žiarových hrobov. Príčiny môžu byt rôzne, od nevhodných pôdnych podmienok (t. j., že sa nezachovali iné, než žiarom zakonzervované rastlinné zvyšky), charakteru pohrebných obradov, stavu bádania vo vybraných regiónoch až po typicky l'udské faktory ako nepozornost̉ pri vyberaní nálezov alebo nezáujem o akékolvek vzorkovanie, dôsledné preplavovanie uloženín bezo zvyšku a pod. 


\section{ZÁVER}

Pestované rastliny v zuholnatenej podobe, zaevidované v rámci systematického výskumu pohrebiska v Cinobani, patria trom botanickým taxónom. V piatich prípadoch ide o hrach siaty (Pisum sativum), $\mathrm{v}$ jednom prípade o zrno jačmeňa siateho nahozrnového (Hordeum vulgare var. coeleste) a semeno prosa siateho (Panicum miliaceum). Všetky semená hrachu aj so zrnami obilnín sa našli vo výplniach (rôznych typov) nádob. Tieto nálezy dokumentujú, že na pohrebnej hranici sa spolu s telom zosnulého spalovali tiež obilniny a strukoviny, z ktorých čast' sa dostala i do hrobu. Podobne, napríklad o zachytenom okamihu techniky kremácie (vhadzovaní obilia do ohňa hranice pri kremačnom obrade a pod.), ale už pri komentovaní archeobotanickej analýzy materiálu z výplne hrobovej keramiky uvažovali aj M. Hajnalová a J. Katkinová $(2002,23)$.

Hodnotit nálezy plodín získané na pohrebisku v Cinobani z hladiska sortimentu pestovaných plodín alebo pol'nohospodárskych postupov je velmi problematické. Spôsobuje ho nízky počet nálezov (obr. 15) aj skutočnost', že ich výskyt odzrkadluje pravdepodobne zvyky pohrebných rituálov, a nie ekonomické stratégie (napr. agrotechnické postupy). Preto, ak vylúčime možnost̉ kontaminácie materiálom z iných období ( $\mathrm{v}$ našom prípade z doby laténskej a z novoveku), tak je možné iba konštatovanie, že v dobe popolnicových polí v oblasti Cinobane, resp. na západe Slovenského rudohoria, obyvatelia poznali ekologicky nenáročné obilniny, jačmeň siaty nahozrnový (Hordeum vulgare var. coeleste) a proso siate (Panicum miliaceum). Tieto v sledovanom mikroregióne (obr. 16) indikujú možnost̉ obhospodarovania pôd nižšej kvality. Súveké obyvatel'stvo podhorských a do istej - väčšej (?) miery odlesnených oblastí, sa venovalo skôr pastierstvu a menej intenzívnemu obrábaniu polí. Jasné doklady špecializovanej remeselnej výroby (napr. metalurgie farebných kovov) sa na sídlisku ani hradisku v Cinobani zatial' nepotvrdili.

Domnievame sa, že pokračovanie cielených a plánovaných odberov archeobotanických vzoriek na pohrebiskách z doby popolnicových polí, napríklad v záujmovom teritóriu na juhu stredného Slovenska, bude nápomocné pri interpretácii javov a skutočností spätých s (polno)hospodárstvom a v neposlednom rade i pohrebným rítom mladších stupňov doby bronzovej. Tento trend však záleží aj od možností užšej spolupráce archeológov s odborníkmi z iných vedných odborov priamo na terénnych výskumoch.

\section{LITERATÚRA}

Anderberg 1994

Beijerinck 1947

Bojňanský/Farkašová 2007

Červenka a kol. 1986

Dostál/Červenka 1991

Furmánek 2015

Furmánek/Mitáš 2010a

Furmánek/Mitáš $2010 b$

Furmánek/Mitáš 2011

Furmánek/Mitáš 2013

Furmánek/Mitášs, v tlači

Gyulai 2010
A. L. Anderberg: Atlas of seeds and small fruits of Northwest-European plant species (Sweden, Norway, Denmark, East Fennoscandia, Iceland) 4. Resedaceae-Umbelliferae. Stockholm 1994.

W. Beijerinck: Zadenatlas der Nederlandsche Flora. Wageningen 1947.

V. Bojňanský/A. Farkašová: Atlas of seeds and fruits of Central and East-European flora. The Carpathian Mountains Region. Dordrecht 2007.

M. Červenka: Slovenské botanické názvoslovie. Príroda. Bratislava 1986.

J. Dostál/M. Červenka: Vel'ký kl'úč na určovanie vyšších rastlín I, II. Bratislava 1991.

V. Furmánek (zost.): Staré Slovensko 4. Doba bronzová. Nitra 2015.

V. Furmánek/V. Mitáš: Cinobaňa - eine weitere bedeutende Fundstelle aus der Urnenfelderzeit in der Slowakei. Das Altertum 55, 2010, 33-58.

V. Furmánek/V. Mitáš: Pohřební ritus západní enklávy jihovýchodních popelnicových polí. Analýza pohřebište v Radzovcích (Slovensko). Památky archeologické 101, 2010, 39-110 a príloha.

V. Furmánek/V. Mitáš: Výskum pohrebiska kyjatickej kultúry v Cinobani. AVANS 2008, 2011, 93-95, 299-301.

V. Furmánek/V. Mitáš: Pokračovanie výskumu v Cinobani. AVANS 2009, 2013, 101-102, 288-289.

V. Furmánek/V. Mitáš: Siedma sezóna výskumu pohrebiska v Cinobani. AVANS 2014, v tlači.

F. Gyulai: Archaeobotany in Hungary. Seed, Fruit, Food and Beverage Remains in the Carpathian Basin from the Neolithic to the Late Middle Ages. Budapešt 2010.

Pod'akovanie

Za podnetné komentáre a odbornú konzultáciu d’akujeme doc. Mgr. Márii Hajnalovej, PhD. 
Hajnalová E. 1976

Hajnalová E. 1978a

Hajnalová E. $1978 b$

Hajnalová E. 1985

Hajnalová E. 1990

Hajnalová E. 1993

Hajnalová E. 1994

Hajnalová E. 1999

Hajnalová E./Hajnalová M./Mihályiová 2003

E. Hajnalová: Prehlad botanických nálezov z výskumov Archeologického ústavu SAV v roku 1975. AVANS 1975, 1976, 95-100.

E. Hajnalová: Nálezy rastlín na pohrebiskách v pravekom a včasnohistorickom období Slovenska a ich úloha v pohrebnom ríte. Archeologické rozhledy 30, 1978, 123-132.

E. Hajnalová: Prehlad nálezov a analýz rastlinných makrozvyškov z archeologických výskumov. AVANS 1977, 1978, 78-91.

E. Hajnalová: Paleobotanické nálezy zo sídlisk, jaskýň a objektov výrobného charakteru. AVANS 1984, 1985, 89-95.

E. Hajnalová: Podiel výrobnej a ostatnej činnosti človeka na Sitne v minulosti a zmena životného prostredia na základe paleobotanických poznatkov. Študijné zvesti AÚ SAV 26, 1990, 105-110.

E. Hajnalová: Obilie v archeobotanických nálezoch na Slovensku. Acta Interdisciplinaria Archaeologica 8. Nitra 1993.

E. Hajnalová: Katalóg archeobotanických nálezov z lokalít na západnom Slovensku z mladšej a neskorej doby bronzovej a $\mathrm{z}$ doby halštatskej. In: L. Veliačik/ P. Romsauer: Vývoj a vzt'ah osídlenia lužických a stredodunajských popolnicových poli na západnom Slovensku. I - Katalóg. Nitra 1994, 258-264.

E. Hajnalová: Archeobotanika pestovaných rastlín. Učebné texty pre dištančné štúdium. Nitra 1999.

E. Hajnalová/M. Hajnalová/J. Mihályiová: Archeobotanické nálezy zo starších archeologických výskumov na Slovensku. AVANS 2002, 2003, 47-50.

Hajnalová E./Poláčik 1999

Hajnalová M./Hajnalová E. 1998

Hajnalová M. 2012

Hajnalová M. 2013

Hajnalová M./Katkinová 2002

Jacomet 2006

Jones 1991

Kühn 1981

Mihályiová 2009

Mihályiová 2010a

Mihályiová $2010 b$

Mihályiová 2010c

Mihályiová 2014

Mihályiová $2015 a$

Mihályiová 2017

Mihályiová $2015 b$

MihályioválZachar 2016
E. Hajnalová/Š. Poláčik: Vyhodnotenie vrstvy semien na základe archeobotanických a štatistických údajov na lokalite Zemianske Podhradie, poloha Hradištia. Študijné zvesti AU SAV 33, 1999, 161-192.

M. Hajnalová/E. Hajnalová: Preplavovanie - metóda získavania rastlinných makrozvyškov z archeologických objektov a vrstiev. Informátor SAS pri SAV 8, 1998, 6, 7. M. Hajnalová: Archeobotanika doby bronzovej na Slovensku. Štúdie ku klíme, prírodnému prostrediu, polnohospodárstou a paleoekonómii. Nitra 2012.

M. Hajnalová: Plant macroremains from Lusatian Culture features at Hajná Nová Ves. In: E. Wiedermann (ed.): The Prehistoric Multicultural Settlement of Hajná Nová Ves (Slovakia). Cultural-historical, settlement-archaeological and archaeo-environmental contexts in Western Carpathia at the end of the early prehistoric and in the late prehistoric periods. BAR International Series 2482. Oxford 2013, 135-139.

M. Hajnalová/J. Katkinová: Ilava-Porubská dolina, lužické žiarové pohrebisko: archeobotanická analýza výplne vybraných nádob. Študijné zvesti AÚ SAV 35, 2002, 19-26.

S. Jacomet (ed.): Identification of cereal remains from archeological sites. $2^{\text {nd }}$ edition. Basel 2006.

G. E. M. Jones: Numerical analysis in archeobotany. In: W. van Zeist/K. Wasylikowa/K.-E. Behre (eds.): Progress in the Old World Palaeethnobotany. A retrospective view on the occasion of 20 years of the International Work Group for Palaeoethnobotany. Balkema - Rotterdam - Brookfield 1991, 63-80.

F. Kühn: Rozbory nálezů polních plodín. Přehled výzkumů 1979, 1981, 75-79.

J. Mihályiová: Cinobaňa. Výskumná správa 16858/2009. Dokumentácia AÚ SAV v Nitre. Nitra 2009. Nepublikované.

J. Mihályiová: Cinoban̆a. Výskumná správa 17287/2010. Dokumentácia AÚ SAV v Nitre. Nitra 2010. Nepublikované.

J. Mihályiová: Cinobaňa. Výskumná správa 17288/2010. Dokumentácia AÚ SAV v Nitre. Nitra 2010. Nepublikované.

J. Mihályiová: Cinobaňa. Výskumná správa 17733/2010. Dokumentácia AÚ SAV v Nitre. Nitra 2010. Nepublikované.

J. Mihályiová: Cinobaňa. Výskumná správa 18661/2014. Dokumentácia AÚ SAV v Nitre. Nitra 2014. Nepublikované.

J. Mihályiová: Cinobaňa. Výskumná správa 18925/2015. Dokumentácia AÚ SAV v Nitre. Nitra 2015. Nepublikované.

J. Mihályiová: Cinobaňa. Výskumná správa 19118/2017. Dokumentácia AÚ SAV v Nitre. Nitra 2017. Nepublikované.

J. Mihályiová: Archeobotanické výsledky z výskumu žiarového pohrebiska kyjatickej kultúry v Cinobani. In: Ožd’áni, O. (ed.): Popolnicové polia a doba halštatská. Zborník referátov z XII. medzinárodnej konferencie "Doba popolnicových polí a doba halštatská" Hriňová-Polana 14.-18. máj 2012. Nitra 2015, 149-157. štatskej a z obdobia popolnicových polí. AVANS 2011, 2016, 174-176.
J. Mihályiová/T. Zachar: Rastlinné makrozvyšky z vybraných pohrebísk doby hal- 
Mitáš 2016

Mitáš/Furmánek 2015a

Mitáš/Furmánek $2015 b$

Mitáš/Furmánek 2016

Mitáš/Furmánek 2017

Mitáš/Furmánek 2018

Parma a i. 2016

Parma a kol. 2017

Studeníková/Paulík 1983

Tempír 1969

Schermann 1967

Schweingruber 1978

Stika 2011

Stika/Heiss $2013 a$

Stika/Heiss $2013 b$

Wiedermann 2013

\section{Macroremains of Cultivated Plants in Burials \\ from the Urnfield Period in Cinobaňa}

\author{
Jana Mihályiová - Vladimír Mitáš
}

Internetový zdroj

http://ncpvat.cvtisr.sk/buxus/docs//Veda_v_CENTRE/VvC_2016/strukoviny.pdf [18. 5. 2018]
Študijné zvesti AÚ SAV 59, 2016, 171-182.

V. Mitáš/V. Furmánek: Pohrebisko kultúrneho komplexu juhovýchodných popolnicových polí v Cinobani (Výskum v rokoch 2007-2012). In: O. Oždáni (ed.): Popolnicové polia a doba halštatská. Zborník referátov z XII. medzinárodnej konferencie „Doba popolnicových polí a doba halštatská" Hriňová-Pol’ana 14.-18. máj 2012. Nitra 2015, 159-189.

V. Mitáš/V. Furmánek: Tretia sezóna výskumu pohrebiska v Cinobani. AVANS 2010, 2015, 160-162, 314-316.

V. Mitáš/V. Furmánek: Štvrtá sezóna výskumu pohrebiska v Cinobani. AVANS 2011, 2016, 176-177, 303-304.

V. Mitáš/V. Furmánek: Výskum pohrebiska pilinskej a kyjatickej kultúry v Cinobani. AVANS 2012, 2017, 125, 126, 201, 202.

. Mitáš/V. Furmánek: Výskum pohrebiska v Cinobani. AVANS 2013, 2018, 126-127. D. Parma/M. Hajnalová/J. Kala/R. Kočárová/P. Kos/R. Křivánek: Pohřebiště v Podolí u Brna a fenomén žárových hrobů mladší doby bronzové s rozměrnými jámami na Moravě. Archeologické rozhledy 68, 2016, 291-332.

D. Parma a kolektív: Archeologie střední a mladší doby bronzové na Vyškovsku. Interpretační potenciál plošných záchranných výzkumi. Brno 2017.

E. Studeníková/J. Paulík: Osada z doby bronzovej v Pobedime. Bratislava 1983.

Z. Tempír: Archeologické nálezy zemědělských rostlin a plevelů na Slovensku. Agrikultúra 8, 1969, 7-66.

Sz. Schermann: Magismeret II. Budapest 1967.

F. H. Schweigruber: Mikroscopic Wood Anatomy. Zug 1978.

H.-P. Stika: Beer in Prehistoric Europe. In: W. Schiefenhövel/ H. Macbeth (eds.): Liquid Bread. Beer and Brewing in Cross-Cultural Perspective. New York - Oxford 2011, 55-62.

H.-P. Stika/A. G. Heiss: Bronzezeitliche Landwirtschaft in Europa - Der Versuch einer Gesamtdarstellung des Forschungsstandes. In: K.-H. Willroth (Hrsg.): Siedlungen der älteren Bronzezeit. Beiträge zur Siedlungsarchäologie und Paläoökologie des zweiten vorchristlichen Jahrtausends in Südskandinavien, Norddeutschland und den Niederlanden. Workshop von 7. bis 9. April in Sankelmark. Mainz 2013, 189-222.

H.-P. Stika/A. G. Heiss: Plant Cultivation in the Bronze Age. In: H. Fokkens/A. Harding (eds.): The Oxford Handbook of the European Bronze Age. First Edition. Oxford 2013, 348-369.

E. Wiedermann: The Prehistoric Multicultural Settlement of Hajná Nová Ves (Slovakia). Cultural-historical, settlement-archaeological and archaeo-environmental contexts in Western Carpathia at the end of the early prehistoric and in the late prehistoric periods. BAR International Series 2482. Oxford 2013.

\author{
Summary
}

The authors pay closer attention to the macroremains of cultivated plants at the cremation burial ground from the Late Bronze Age (around 1200-750 BC) in Cinobaňa, Poltár district. Between 2008 and 2014, 314 burials were systematically investigated and 730 archaeobotanical samples were collected under the supervision of V. Furmánek and Vladimír Mitáš (IA SAS, Nitra). Sampling strategy for collecting archaeobotanical material was systematic. Samples were collected by judgement sampling strategy (Jones 1991) from features with a determined function, i. e. from burials and vessels deposited in them. Plant macroremains assemblage consists of 4730 finds in which charcoal from deciduous trees used at cremations represent a majority. Macroremains of cultivated plants are rare and were identified 
in seven graves - mainly from the Kyjatice culture, one from the Piliny culture. Five finds are seeds of sweet pea (Pisum sativum), one is naked barley (Hordeum vulgare var. coeleste) and one is proso millet (Panicum miliaceum). The pea was discovered in a bowl from burial 137/10, in an amphora covered with a bowl in burial 235/12, in a lid covered with a torso of a vessel in burial 265/13, in amphora covered with a bowl in burial 285/13 and in an amphora probably originally covered with a bowl from burial 301/14. Grain of naked barley was found in the sample from one of the urns - amphora from burial 155/10. A small amphora from burial 271/13 contained a grain of proso millet. Vessels with detected macroremains of cultivated plants are typologically and functionally heterogeneous group representing the urns as well as "pottery (?)" added as "grave goods". Two burials from the Late Bronze Age with above-standard number of pottery vessels - 20 exemplars - occur in the analysed group. It is yet unclear, whether there is a direct (hypothetical) connection between the number of vessels in the burials ("rich" graves) and the presence of cultivated plants. Nevertheless, the number of finds is low and the assortment of cultivated plants is narrow in spite of the very intensive sampling - 314 burials were studied, most of them were archaeobotanically sampled and 755 litres of soil were processed by flotation. The generally low number of plant macroremains in the extensively sampled assemblage from the burial ground in Cinobaňa also due to the local pedologic conditions (acid cambisol) which are generally not favourable for preservation of organic remains. The assortment of plants from Cinobaňa which is mediated and preserved thanks to the burial rite gives an indirect evidence of their utilisation and possibly local cultivation in the southwest of the Slovenské rudohorie mountains in the Urnfield period. Occurrence of ecologically undemanding cereals - naked barley (Hordeum vulgare var. coeleste) and proso millet (Panicum miliaceum) - might point to exploitation of soils of lower quality and or other specific features of the Urnfield period's environment in the studied (micro)region.

Fig. 1. Cinobaňa. Environment of the sites from the Urnfield period and their positions in the landscape. Legend: $\mathrm{a}$ - settlement, $\mathrm{b}$ - burial ground, $\mathrm{c}$ - hillfort. Photo by V. Mitáš.

Fig. 2. Cinobaňa. Investigation of the burial ground in 2013. Photo by V. Mitáš.

Fig. 3. Cinobaňa. Grave 137/10. Photo by V. Mitáš.

Fig. 4. Cinobaňa. Grave 155/10. Photo by V. Mitáš.

Fig. 5. Cinobaňa. Grave 235/12. Photo by V. Mitáš.

Fig. 6. Cinobaňa. Grave 265/13. 1 - whole, 2 - detail of the spot of archaeobotanical find. Photo by V. Mitáš.

Fig. 7. Cinobaňa. Grave 271/13. Photo by V. Mitáš.

Fig. 8. Cinobaňa. Grave 285/13. Photo by V. Mitáš.

Fig. 9. Cinobaňa. Grave 301/14. Photo by D. Marková.

Fig. 10. Burial pottery in the process of washing. Photo by V. Mitáš.

Fig. 11. 1 - Barley (Hordeum distichon var. nudum; according to Jacomet 2006); 2 - find barley (Hordeum vulgare var. coeleste) from the burial ground in Cinobaňa (photo by J. Mihályiová).

Fig. 12. 1 - Proso millet (Panicum miliaceum; according to Jacomet 2006); 2 - find from the burial ground in Cinobaňa (photo by J. Mihályiová).

Fig. 13. 1 - Pea (Pisum sativum; according to Bojňanský/Farkašová 2007); 2 - find from the burial ground in Cinobaňa (photo by J. Mihályiová).

Fig. 14. Cinobaňa. 1 - bowl of the Kyjatice culture with an archaeobotanical find Pisum sativum; 2 - amphora of the Kyjatice culture with an archaeobotanical find Hordeum vulgare var. coeleste; 3 - a small amphora of the Kyjatice culture with an archaeobotanical find Panicum miliaceum. Drawing by Z. Nagyová, photo by V. Mitáš.

Fig. 15. Cinobaňa. Localization of macroremains of cultivated plants over the investigated area of the burial ground. Legend: $a$ - cereal; $b$ - legumes. Author of the plan V. Mitáš.

Fig. 16. Cinobaňa. Agricultural use of the settlement location at present. Photo by V. Mitáš.

Table 1. Cinobaňa. Overview of finds in analysed graves.

Translated by Mgr. Viera Tejbusová

Ing. Jana Mihályiová

Archeologický ústav SAV

Akademická 2

SK - 94921 Nitra

nraujmih@savba.sk
PhDr. Vladimír Mitáš, PhD.

Archeologický ústav SAV

Akademická 2

SK - 94921 Nitra

vladimir.mitas@savba.sk 